\title{
LA MUSEOGRAFÍA EN CUSCO: DIFERENTES MUSEOS, DIFERENTES NARRATIVAS
}

\author{
MUSEOGRAPHY IN CUZCO: DIFFERENT MUSEUMS, DIFFERENT \\ NARRATIVES
}

\author{
Richard L. Burger ${ }^{1}$ y Lucy C. Salazar ${ }^{1}$
}

\begin{abstract}
Este trabajo tiene como enfoque de análisis cuatro museos ubicados en la ciudad de Cusco, Perú. Cada uno presenta elementos relacionados con la cultura Inca, aunque el contexto y el tratamiento varia radicalmente entre ellos. Argüimos que estos museos ofrecen diferentes alternativas en su narración, que reflejan la visión de los individuos y/o instituciones responsables de estas exhibiciones y la audiencia a quien se dirigen. Los museos serán comparados no solamente en términos de sus narrativas, sino también, en relación a las técnicas museográficas utilizadas y sus ambientes. Se sugiere que en vez de considerarlos como instituciones competitivas puedan ser interpretados como complementarios, cada uno ofreciendo una visión diferente del pasado cuzqueño y su relación al Cusco contemporáneo y la cultura peruana.
\end{abstract}

Palabras claves: museos, Cusco, Inca, Machu Picchu, nacionalismo, incanismo, Hiram Bingham.

This article will focus on four museums that currently function in the center of Cuzco, Peru. Each of these museums includes components dealing with the Inca culture, but the context and treatment of this subject varies radically between them. It will be argued that the museums provide alternative narratives that reflect the motives of the individuals responsible for their exhibitions and the audience that is being targeted. The four museums will be compared with each other not only in terms of their contrasting narratives but also in terms of the museographic techniques employed and the settings in which the collections are shown. It will be suggested that rather than being viewed as competing institutions of differing qualities, these museums can be treated as complementary, each providing a different vision of the Cuzqueño past and its relation to contemporary Cuzco.

Key words: Museums, Cuzco, Inca, Machu Picchu, nationalism, Incanism, Hiram Bingham.

Hoy en día Cusco, la antigua capital del Imperio Inca, es una ciudad de provincia de más de medio millón de habitantes que cubre el piso del valle y las laderas de la cuenca formada por los ríos Tullumayo y Saphi. La cantería incaica y la arquitectura colonial son visibles por todo el centro urbano y le dan a la ciudad un profundo sentido histórico comparable con el que se experimenta en Roma o Atenas. En 1983 fue debidamente agregado a la lista de Patrimonio Histórico de la Humanidad de la UNESCO, en tanto que la presencia de los restos incaicos y coloniales es tan omnipresente que Helaine Silverman (2006) sugiere que su distrito histórico puede considerarse un "museo de sitio al aire libre". Esta impresión quedó más reforzada recientemente al colocarse la estatua de un rey inca en la plaza de armas, así como numerosos gráficos explicativos que adornan las calles de la ciudad.

Dentro de este museo de sitio al aire libre, hay una multiplicidad de museos tradicionales que atienden tanto a la población local como al más de un millón de visitantes peruanos y extranjeros que hoy visitan al Cusco cada año, para gozar el centro histórico y usar la ciudad como base para excursiones a sitios arqueológicos incas en los alrededores como Ollantaytambo y Machu Picchu. Si bien hay ocasiones en que los residentes nativos parecen sentirse abrumados por el ingreso de forasteros, están orgullosos de su legado incaico y el quechua, la lengua de los incas, sigue siendo ampliamente hablada por la mayoría de los cuzqueños junto con el español, la lengua oficial del Perú.

Los museos más populares del Cusco están dedicados a la exhibición de objetos antiguos e históricos, pero emplean distintas narrativas sobre el pasado, usando una serie de convenciones y técnicas museográficas. Podemos entender esta diversidad museológica en términos de las influencias históricas, raciales, sociales y globales detrás de su aparición, así como las historias y el contexto individual de cada institución. Algunos de

\footnotetext{
${ }_{1}$ Department of Anthropology, Yale University, New Haven, Connecticut, EEUU. richard.burger@yale.edu; lucy.salazar@yale.edu
} 
los contrastes más interesantes entre estas instituciones radican en la forma en que ven la relación existente entre pasado y presente (Silverman 2008). Si bien tales museos aparentemente se concentran en el pasado, sus exhibiciones también ofrecen visiones contrastantes acerca de la relación existente entre el Cusco contemporáneo, la moderna nación peruana y el pasado incaico imaginado.

Esta diversidad museológica se explorará aquí, describiendo y analizando cuatro de los museos más grandes del Cusco que exhiben el pasado precolombino: el Museo Inka, el Museo Histórico Regional en la Casa Garcilaso de la Vega, el Museo de Arte Precolombino (MAP) y el Museo Machu Picchu en la Casa Concha. Todos ellos se encuentran en el centro histórico de la ciudad, dentro de residencias coloniales restauradas que se construyeron encima de palacios incaicos destruidos.

Debemos señalar de paso que no todos los museos en Cusco se concentran en la antigüedad. Por ejemplo, el Museo del Café, el Museo del Pisco y el Museo del Chocolate están dedicados a comidas populares, y el ahora difunto Museo de Plantas Sagradas, Mágicas y Medicinales estuvo dedicado a los alucinógenos, las hojas de coca y otras drogas. Pero aquí no tendremos en cuenta a estos y muchos otros museos cuzqueños debido a las limitaciones de espacio. Resulta significativo que de todos ellos, los cuatro que se van a examinar aquí son los que cuentan con la mayor asistencia. Les pasaremos revista siguiendo el orden en que se les fundó.

\section{Museo Inka}

El Museo Inka es el más antiguo y popular de la ciudad. Fundado como museo arqueológico en 1848, fue incorporado en 1919 a la Universidad Nacional San Antonio Abad (UNSAAC), la universidad más grande del sur peruano. Tras el devastador terremoto de 1950, el museo fue mudado a su actual ubicación en la Casa del Almirante, una mansión colonial construida en el siglo XVII por el almirante Francisco Alderete Maldonado en el mismo estilo que las mansiones barrocas de Extremadura, en España (Figura 1). Este edificio tiene una larga historia y se cree que estuvo asociado tanto con el Inca Huáscar como con el conquistador Diego de Almagro. La colección de antigüedades de primera categoría aquí guardadas y exhibidas es el producto del trabajo realizado por arqueólogos locales y extranjeros, así como por coleccionistas privados.

$\mathrm{Al}$ ingresar al complejo del museo, el visitante se encuentra con un robusto modelo polícromo de un guerrero incaico de tamaño más grande que lo natural, y un gráfico con una caricatura que indica a padres y niños el comportamiento apropiado a seguir mientras

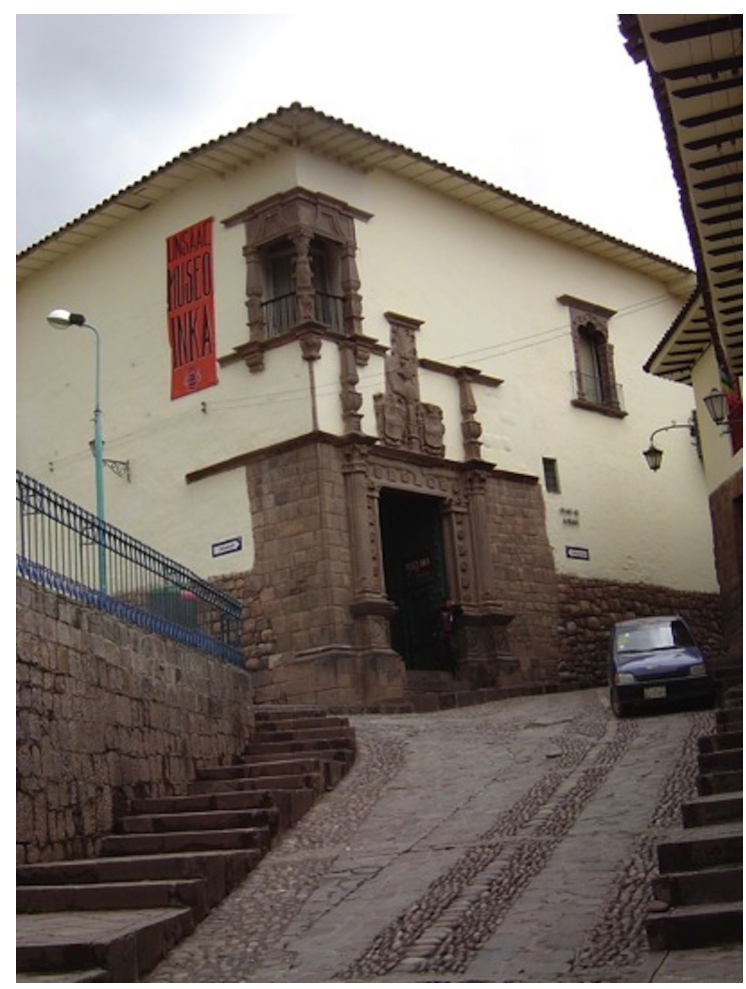

Figura 1. Fachada del Museo Inka, Casa del Almirante. Foto de Helaine Silverman.

Exterior of the Museo Inka, Casa del Almirante. Photo by Helaine Silverman. 
se visita el museo (Figura 2). Al pasar la entrada y la boletería se encuentra el patio central que está ocupado por las tejedoras tradicionales del pueblo de Chincheros. Estas mujeres quechua hablantes usualmente están ocupadas produciendo coloridos cinturones de alpaca y otros textiles en los telares andinos. La presencia de estas mujeres indígenas con su vestimenta tradicional subraya uno de los temas centrales del museo: la continuidad cultural que hay entre la antigua capital de los incas y el Cusco moderno.

En el Museo Inka predomina un interés por la cultura incaica y solo una pequeña parte del mismo está

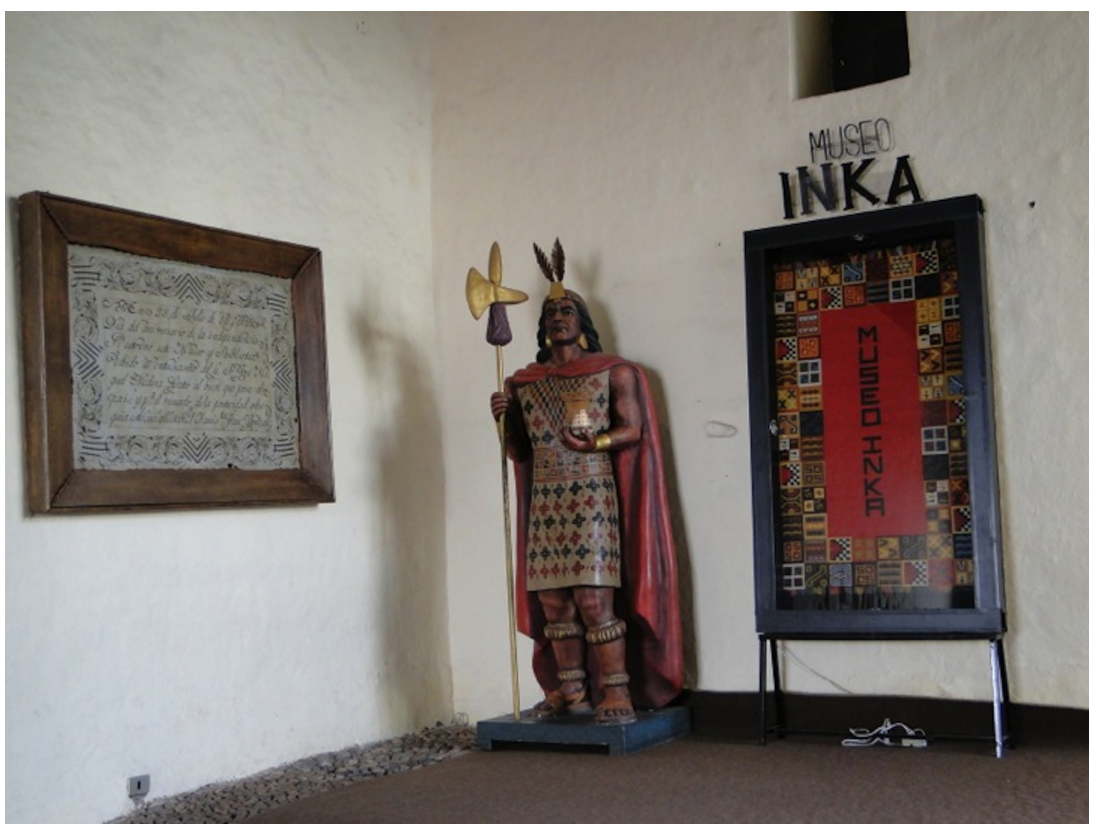

Figura 2. Entrada al Museo Inka. Foto de Helaine Silverman.

Entrance to the Museo Inka. Photo by Helaine Silverman.

dedicada a los antecedentes cuzqueños inmediatos de los incas, a las cuales a veces se conoce como Killke y Lucre. En general, se ignora a las culturas preincaicas de fuera de la zona del Cusco.

Las primeras salas exhiben objetos incaicos organizados según el material del que fueron hechos (madera, piedra, etc.). Se enfatiza su función en lugar de tratárseles tipológicamente. Esto se logra reproduciendo dibujos del artista y cronista colonial Guamán Poma de Ayala, así como ilustraciones modernas en un estilo al cual a veces se conoce como indigenista (Figura 3). En estas galerías se ofrece al visitante una exhibición notable de vasijas de madera para beber a las que se conoce como keros, sandalias de cuero, azadas de piedra, vasijas de cerámica para almacenaje y para preparar chicha de maíz. Algunas de estas piezas son sumamente refinadas en su manufactura y podrían fácilmente exhibirse como arte mayor, pero el interés del museo recae directamente sobre la cultura incaica y lo que se puede aprender a partir de los objetos exhibidos (Figura 4). La mayoría de los objetos en la exhibición son de naturaleza utilitaria y secciones especiales de la muestra se concentran en el pastoreo y la agricultura incaica.
Se examina, además, la religión y la cosmología presentando figurillas de plata martillada, conchas de Spondylus cortadas provenientes de la costa del Ecuador y otros elementos de la parafernalia ritual. El tema de la cosmología y las creencias incas es desarrollado aún más con exhibiciones didácticas de las nociones referidas al cielo nocturno a partir de la etnografía contemporánea. En la sala más popular del museo se lucen momias en una cueva reconstruida, similar a aquella en la cual podrían haber estado enterradas. Esta sección se conoce como "Mallkiwasi" (casa de los antepasados) y en ella se presentan respetuosamente los cuerpos momificados dentro del contexto de las nociones incaicas de la muerte y el más allá (Figura 5). Delante de los cuerpos desecados se han colocado ofrendas de alimentos y comida en vasijas. Una exhibición de este tipo sería inconcebible en los Estados Unidos y en algunos otros países del mundo debido a la aguzada sensibilidad que los restos humanos despiertan, pero en el Cusco esta muestra resalta una creencia en las relaciones recíprocas existentes entre los vivos y los muertos, que muchos cuzqueños siguen teniendo. 


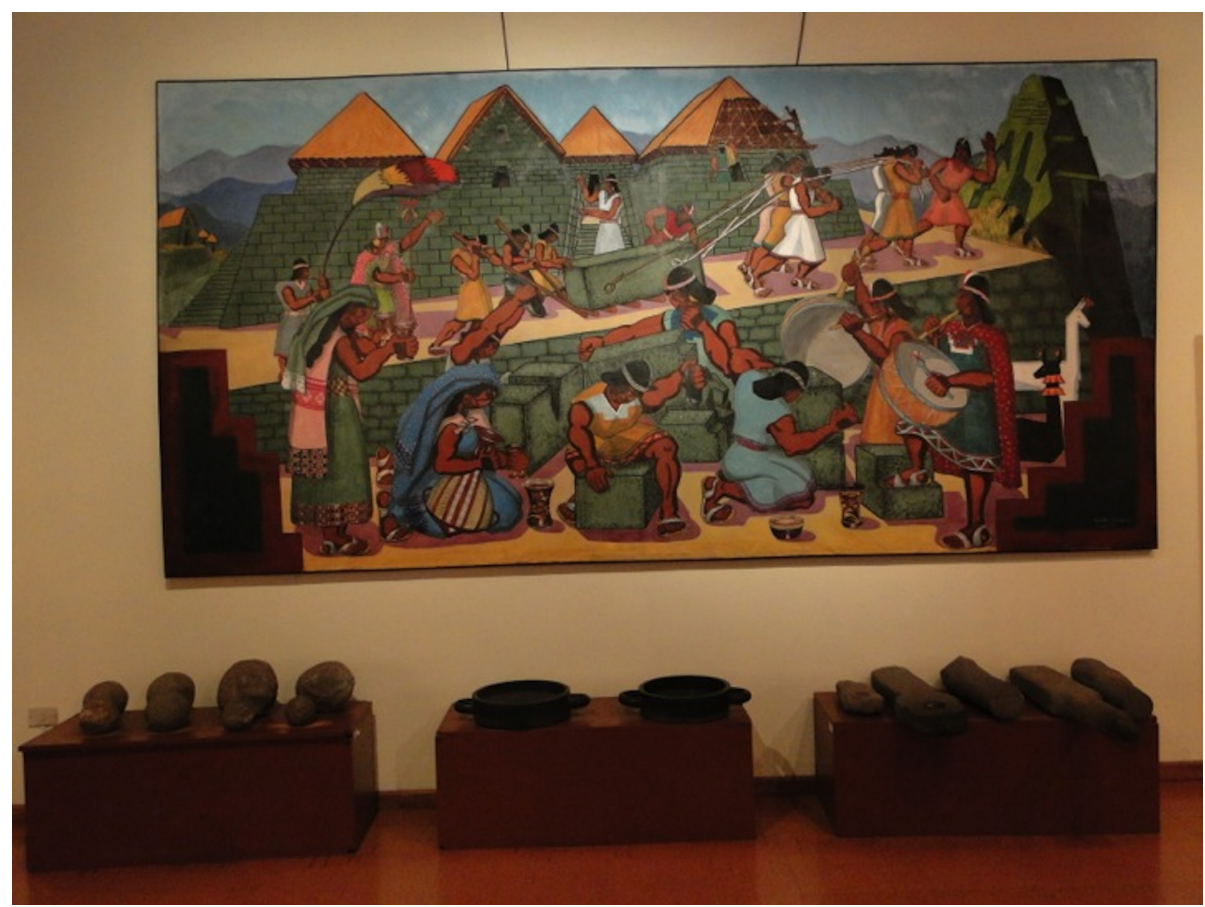

Figura 3. Exhibición de morteros y otros objetos utilitarios con ilustración de estilo indigenista, Museo Inka. Foto de Helaine Silverman.

Exhibition of Inca mortars and other utilitarian objects and illustrated using the "indigenist style of painting", Museo Inka. Photo by Helaine Silverman.

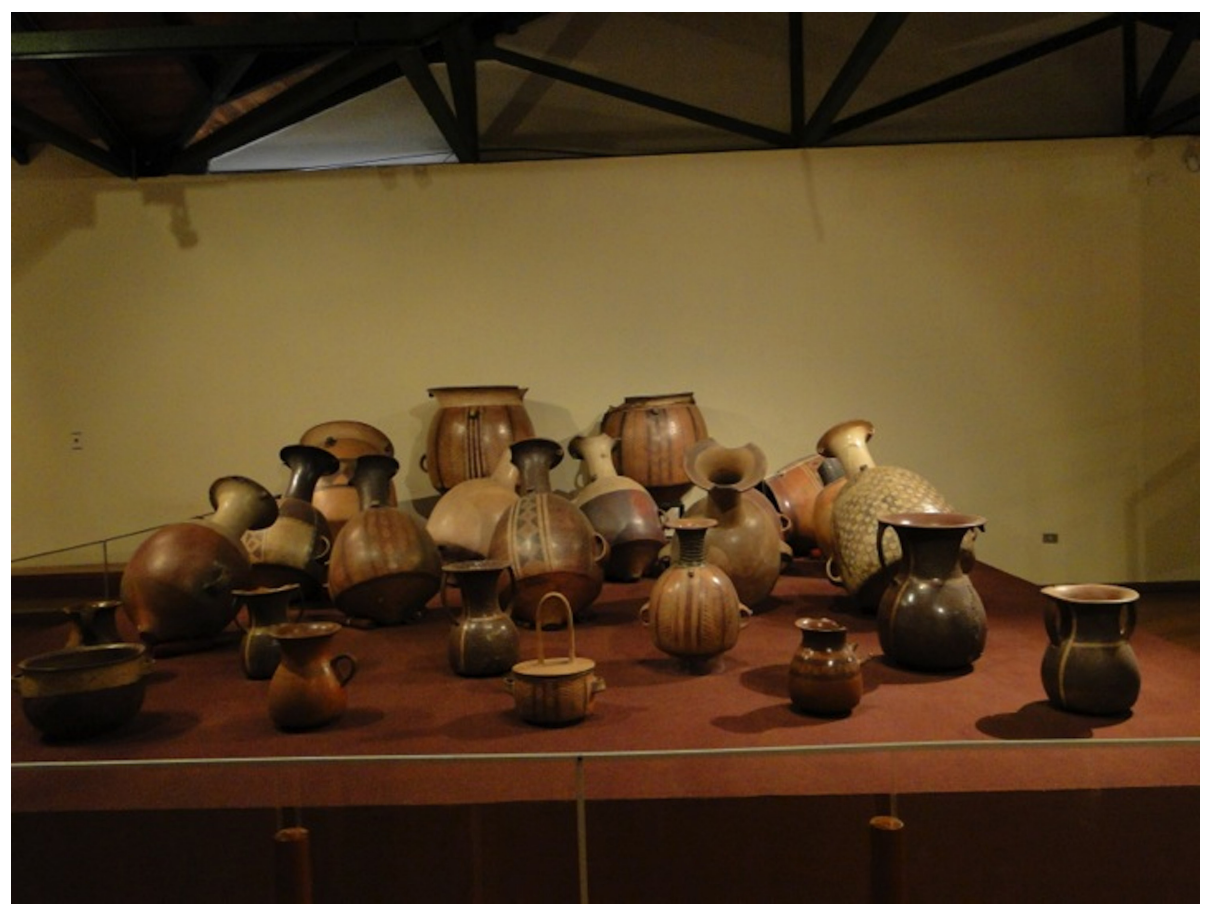

Figura 4. Exhibición de grandes vasijas de almacenaje incaicas (aríbalos) y otra cerámica imperial, Museo Inka. Foto de Helaine Silverman.

Exhibition of large ceramic storage vessels (aryballos) and other imperial pottery, Museo Inka. Photo by Helaine Silverman. 


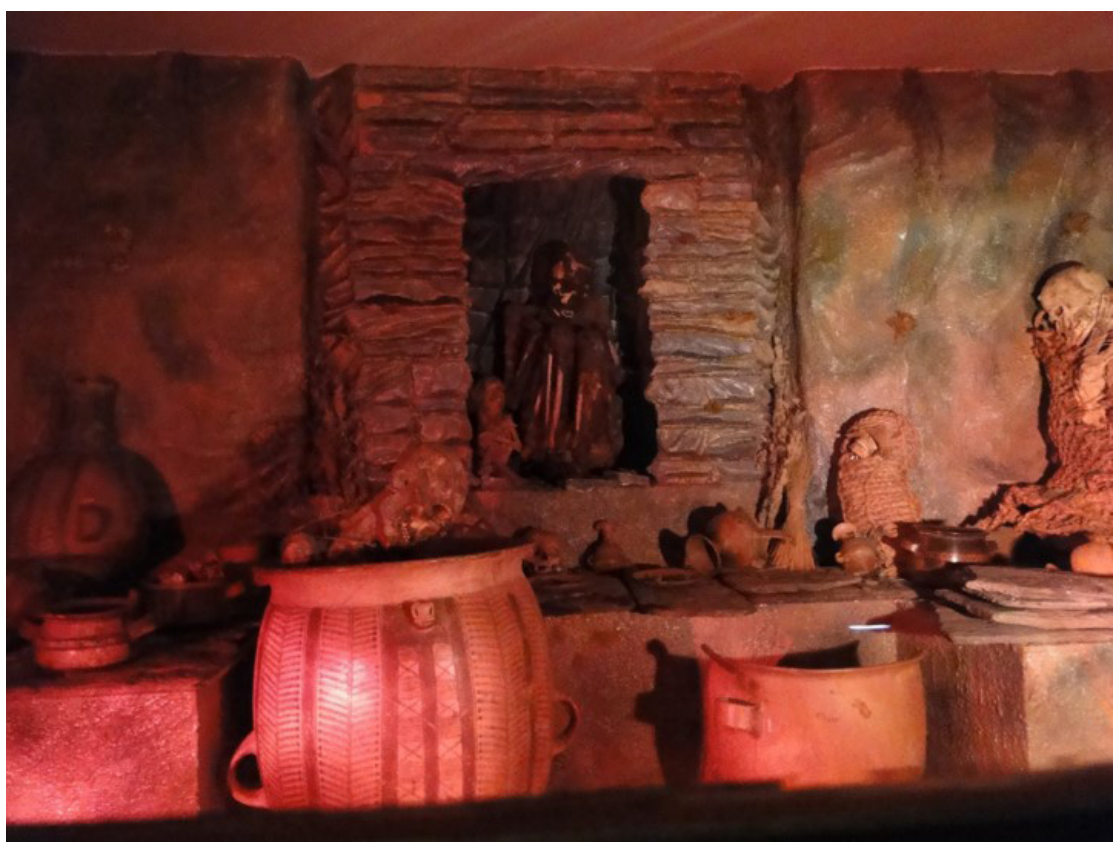

Figura 5. Sala del Mallkiwasi (Casa de los Ancestros), Museo Inka. Foto de Richard Burger.

Gallery of the Mallkiwasi (House of the Ancestors), Museo Inka. Photo by Richard Burger.

De la exhibición de los materiales culturales incaicos se pasa a otra sección, dedicada a la temprana colonia en el Cusco. El arribo de los españoles no es presentado como el inicio de un nuevo periodo temporal o cultural, sino más bien como una invasión que tuvo un impacto traumático sobre la población local. Los objetos de esta época, como su famosa colección de keros coloniales, son mostrados como expresiones de resistencia y se les relaciona explícitamente con los levantamientos indígenas de los siglos XVII y XVIII. $\mathrm{El}$ arte colonial cuzqueño de estos dos siglos se exhibe en una sola habitación, dispuesta como una sala que sugiere el estilo de vida refinado de la élite mestiza que estaba muy lejos del alcance de las masas indígenas. Ello no obstante, cuidadosamente entremezclados con estos materiales hay vasijas rituales coloniales (pacchas) junto con otros objetos, los que dan fe de la supervivencia de las creencias y las prácticas religiosas indígenas.

La siguiente sección del museo se concentra en la importancia renovada que el legado inca ha tenido para la población del Cusco en los siglos XIX y $\mathrm{XX}$, una tendencia a la cual a veces se conoce como inkanismo (Flores Ochoa 1990). Además de estatuas y pinturas que reflejan este renacer de la identificación popular con el pasado incaico, la muestra también incluye fotografías históricas de asociaciones culturales cuzqueñas disfrazadas ejecutando dramas y danzas incas imaginadas.
Es significativo que la última sala del museo esté dedicada a la población quechua hablante del Cusco moderno. Se muestran objetos rituales -entre ellos antiguas tallas en piedra que se han adaptado para nuevos fines, así como un diorama que representa la adivinación con hojas de coca- junto con fotografías de modernos especialistas religiosos andinos. Estas exhibiciones resaltan la conexión que existe entre la cultura de los incas y la cultura indígena del Cusco moderno. Y como para reforzar esto, el visitante, en lugar de salir por una area de souvenirs, debe pasar más bien en medio de las tejedoras de Chincheros, lo que ofrece la oportunidad de apreciar sus técnicas de tejido y comprarles una pieza textil contemporánea.

¿Qué explica la personalidad única del Museo Inka? Desde una perspectiva museográfica, su larga asociación con la UNSAAC ayuda a entender el estilo de su museografía. Las limitaciones del presupuesto de una universidad estatal significan que no es posible incluir vitrinas elegantes o herramientas de alta tecnología, como videos y muestras interactivas. En palabras de una guía de turistas (Tang 2016), su estilo es "charmingly modest" (encantadoramente modesto). La ausencia de textos de buena calidad en inglés sugiere que la prioridad es el público local y nacional, antes que los numerosos extranjeros que lo visitan.

Los estrechos vínculos existentes entre el museo y los docentes de la UNSAAC, en especial los de las facultades de arqueología y antropología, explican su 
perspectiva antropológica. El Dr. Jorge Flores Ochoa, uno de sus más distinguidos profesores, es un eminente antropólogo que durante muchos años fue director o asesor del Museo Inka. Los temas expresados en los textos de este museo hacen eco de sus publicaciones (Flores Ochoa 1990, 2005; Flores et al. 1998). Al igual que en sus escritos, el museo liga la prehistoria, la protohistoria y la etnografía contemporánea en una sola narrativa, cuyo eje siempre es el Cusco, el "centro del universo andino". En todo el museo se ve a la población del Cusco resistiendo heroicamente a fuerzas hostiles, al mismo tiempo que se honra al legado cultural singular heredado del Imperio de los Incas, conocido como Tahuantinsuyu. En general se ignora a los procesos que tienen lugar fuera del Cusco y se presta escasa atención al papel que la nación peruana ha tenido en su historia y estado actual.

En última instancia, el tema central del museo es el empoderamiento y el orgullo de los pobladores nativos del Cusco. El museo busca transmitirle a los forasteros la lucha de los incas y sus descendientes después de la invasión europea, y el mensaje de que la gente indígena en las calles del Cusco es la heredera de su notable legado.

\section{El Museo Histórico Regional, Casa Garcilaso de la Vega}

El Museo Histórico tuvo su origen como el Museo Virreinal en 1946, pero dos décadas más tarde se convirtió en el Museo Histórico Regional y se le mudó a la residencia histórica en donde Garcilaso de la Vega, autor de los "Comentarios Reales de los Incas", nació y vivió hasta los veinte años (Figura 6). Desde su concepción misma el museo se concentró en el legado cultural colonial del Cusco, por lo que el hogar de Garcilaso era un lugar particularmente apropiado. Como hijo de un soldado español y de una princesa inca, Garcilaso encarnó la fusión de las culturas hispana y andina, además de haber sido un ejemplo exitoso de la élite mestiza dominante del Cusco.

Con el traslado del museo en 1967 llegó también su incorporación al sistema nacional de museos del Perú, dándole acceso a recursos adicionales. Dado su nuevo lugar, el museo no solo lucía las glorias de la cultura colonial sino que también rendía homenaje al Inca Garcilaso, una de las principales figuras de aquella época. Por implicación, promovía también la noción del Perú contemporáneo como una nación mestiza, que combinaba la rica tradición cultural europea introducida desde la península ibérica con el legado del pasado indígena. Si bien al principio su eje recaía exclusivamente sobre este legado colonial, su integración al sistema nacional de museos hizo que fuera un lugar lógico donde lucir objetos incas importantes, descubiertos en el transcurso de las investigaciones efectuadas en el Cusco por el Instituto Nacional de Cultura (hoy el Ministerio de Cultura). Ello no obstante, el eje predominante del legado colonial del Cusco persistió hasta que el museo fue renovado a partir de 2010, bajo la dirección de Ana María Gálvez, quien inició su ampliación y modernización, de tal suerte que la descripción siguiente refleja los cambios que ella introdujo.

El Museo Histórico, como ya se señaló, se encuentra actualmente en la residencia quinientista restaurada de Garcilaso de la Vega. La exhibición inicia con un examen del Cusco antes de su ocupación humana con fósiles locales y reconstrucciones artísticas. Las galerías siguientes muestran el desarrollo gradual de las culturas prehispánicas del Cusco desde el Precerámico hasta los incas, utilizando materiales recientemente excavados muchos de los cuales no habían sido exhibidos antes. Los artefactos se complementan con pequeños dioramas, reconstrucciones artísticas y música indígena. Los materiales arqueológicos están ordenados cronológicamente y les acompañan excelentes textos en español e inglés. La última sala del primer piso se concentra en los objetos metálicos incaicos y la tecnología que los produjo (Figura 7). Esta sección está ilustrada no solo con figurillas de oro y plata halladas en el Coricancha, la Plaza Mayor y Sacsahuaman, sino también con una reconstrucción del horno andino alimentado con el viento (conocido como huayrachina) que se usaba para fundir minerales; para dramatizar el flujo del metal derretido desde el horno se emplea una iluminación teatral. En suma, el primer piso del museo presenta el gradual desarrollo de la cultura cuzqueña a lo largo de muchos milenios, hasta su culminación con el Imperio Inca. En el transcurso de esta exhibición se revela que los logros culturales, tecnológicos y políticos de los incas tenían profundas raíces en el valle del Cusco y su hinterland, y que ellos son los legítimos ancestros de la cultura cusqueña.

El segundo piso ofrece una narrativa muy distinta, que inicia con una sala que enfatiza la combinación de elementos españoles y andinos. Ella luce ejemplos de sincretismo religioso como el vínculo entre el santo católico Santiago Matamoros e Illapa, el dios andino del trueno. Pero en las siguientes salas el eje se desplaza a una visión de la cultura colonial en la cual los elementos indígenas tienen poco espacio. El proceso de evangelización del campo por parte de distintas órdenes católicas se describe con una banda sonora de cantos gregorianos, en tanto que distintas clases de objetos de arte católico, desde óleos impresionantes hasta pequeños artículos portátiles, ilustran esta narrativa. A diferencia del Museo Inka, no se hace ninguna mención de las prácticas religiosas andinas que han sobrevivido, ni tampoco de las opresivas campañas efectuadas para 


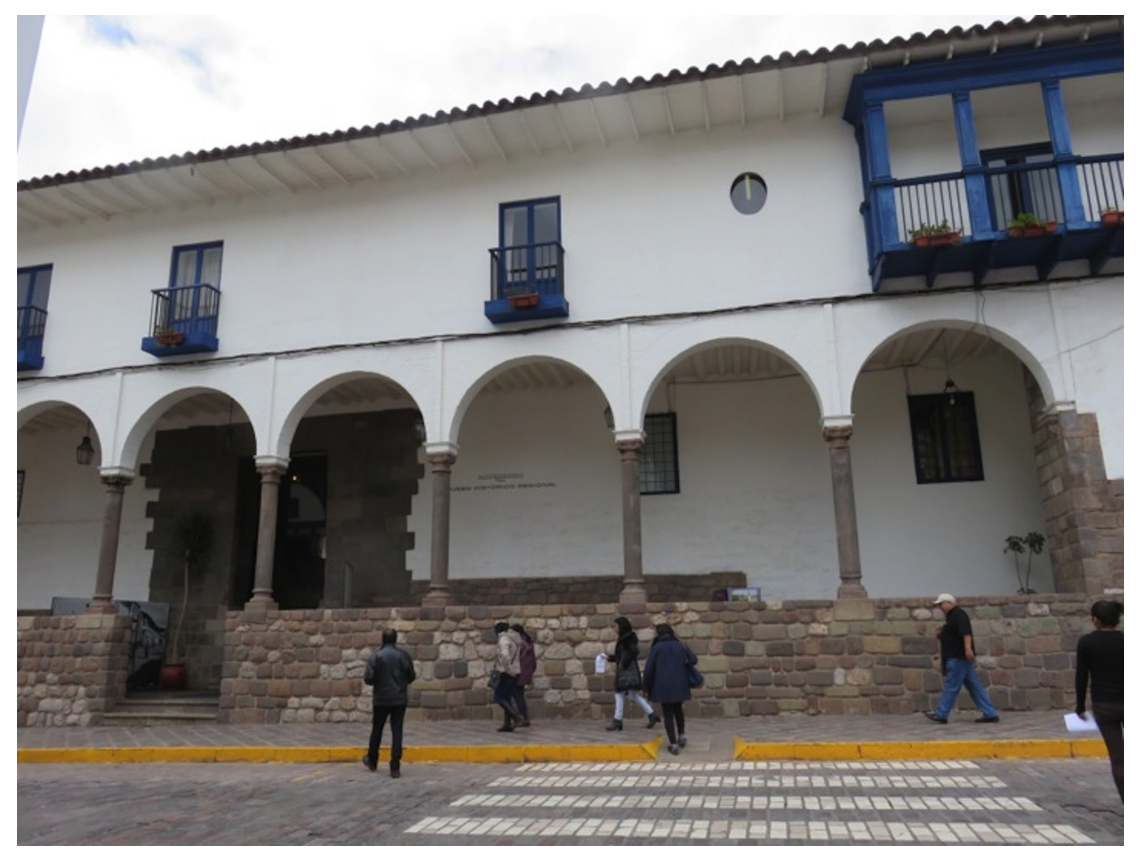

Figura 6. Fachada del Museo Histórico Regional, Casa Garcilaso de la Vega, Cusco. Foto de Richard Burger.

Exterior of the Museo Histórico Regional. Casa Garcilaso de la Vega, Cuzco. Photo by Richard Burger.

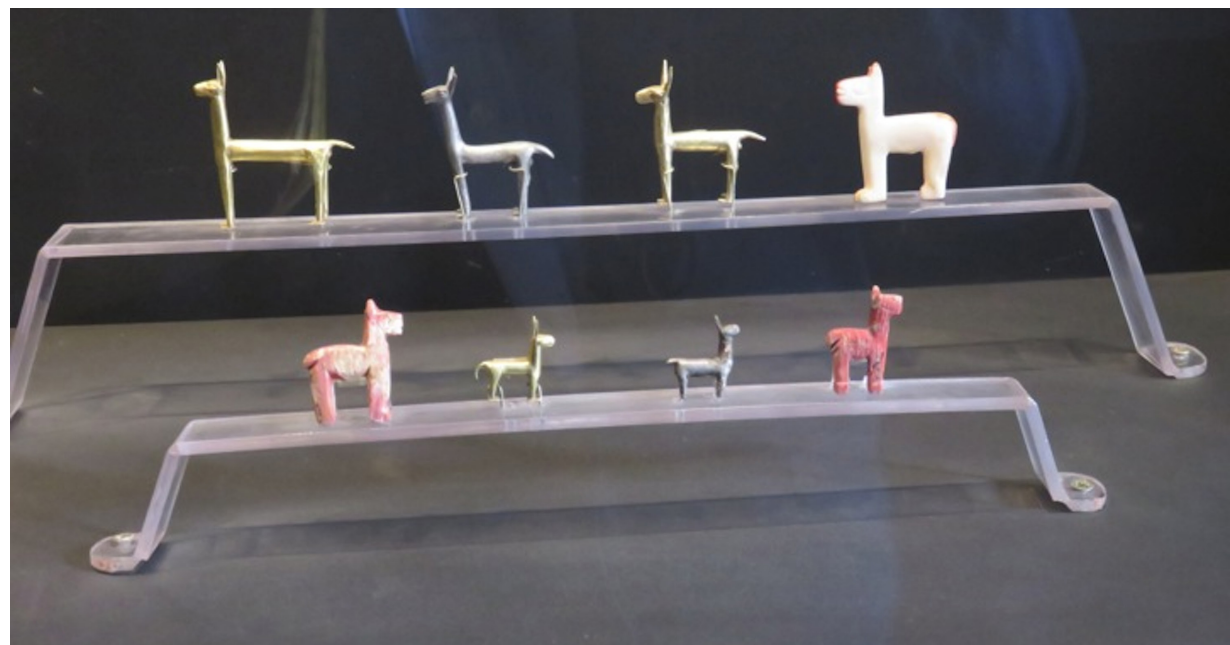

Figura 7. Pequeñas representaciones incaicas de llamas en oro, plata y concha de Spondylus, Museo Histórico Regional. Foto de Richard Burger.

Miniature Inca representations of llamas made in gold, silver and Spondylus shell, Museo Histórico Regional. Photo by Richard Burger.

extirpar las "idolatrías" andinas; no se exhibe ningún artículo que refleje la existencia continua de la cultura indígena. En una habitación se describe el desarrollo de una cocina distintiva entre la élite del Cusco, como un antecedente del boom contemporáneo de la gastronomía peruana (Figura 8). La población indígena se pierde de vista en toda esta sección del segundo piso, y lo que predomina es una visión idealizada de una población mestiza hispanizada.

Este discurso se interrumpe brevemente por una sala dedicada íntegramente al levantamiento indio contra el Imperio Español que tuvo lugar a 


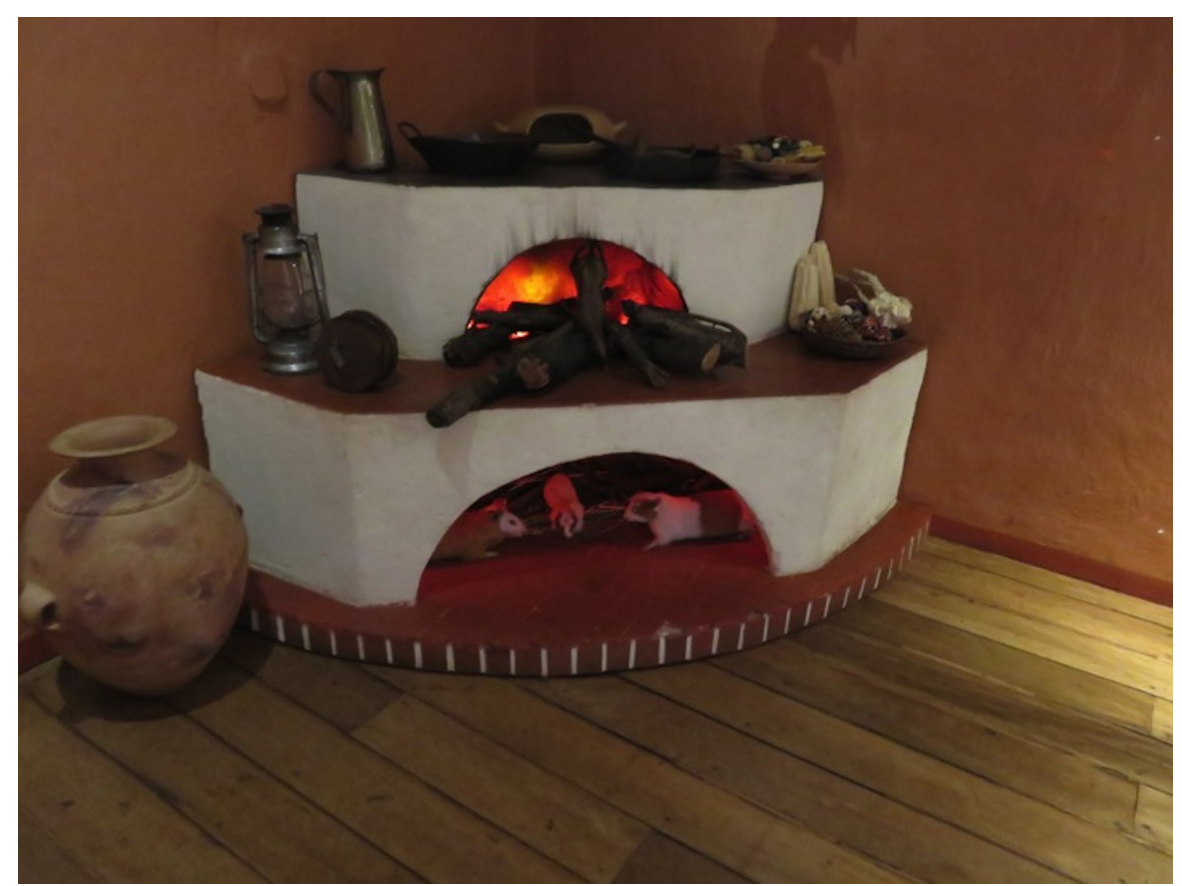

Figura 8. Modelo a escala real del horno andino tradicional en la sala dedicada a la cocina peruana, Museo Histórico Regional. Foto de Richard Burger.

Full-scale model of a traditional Andean oven in a gallery dedicated to Peruvian cuisine, Museo Histórico Regional. Photo by Richard Burger.

finales de 1780, y que fuera liderado por José Gabriel Condorcanqui (a quien también se conoce como Tupac Amaru II). Una pintura al óleo y un video que se concentra en su ejecución en la Plaza de Armas de Cusco, transmiten el dramatismo de este trágico acontecimiento histórico; además, un crucifijo que estuvo presente en la ejecución añade peso emocional a la muestra. Las modernas representaciones textiles indígenas de la muerte de Tupac Amaru II y el vínculo de esta tragedia con las actuales manifestaciones políticas en el Cusco, sugieren la continua relevancia que este acontecimiento tiene para la moderna vida peruana. Y sin embargo, en las galerías que siguen a esta exhibición, el programa del museo regresa a un eje único, el cual gira en torno a la vida de la élite mestiza durante el virreinato con una exhibición que muestra pinturas al óleo, muebles y artículos personales de lujo importados de Europa para su uso por parte de la clase alta cuzqueña.

La última sección del museo es un homenaje al Inca Garcilaso de la Vega, el primer autor hispanoamericano. Ella incluye un video biográfico, ejemplares originales de sus libros, representaciones de él con sus padres, y un modelo del gran escritor trabajando en su escritorio (Figura 9). Un textil fabricado para Garcilaso en Europa y que fuera donado al museo por el gobierno español, se luce en lugar prominente. La exhibición se cierra señalando que Garcilaso prefirió permanecer en España antes que regresar al Perú debido a la ejecución de Tupac Amaru II y a la persecución de los mestizos. Una nota final indica que parte de sus cenizas fueron devueltas al Perú recientemente a pedido del rey de España.

Podemos ver por lo anterior que el Museo Histórico presenta una visión sumamente distinta que la del Museo Inka. Se remonta a los orígenes de los incas muy atrás en la prehistoria y se les presenta simplemente como una más en una larga línea de culturas prehispánicas que habitaron el valle del Cusco. La transformación cultural desatada por la invasión española del Tahuantinsuyu aparece como un proceso histórico que llevó la cultura hispana y el cosmopolitismo europeo al Cusco. Cuando tomamos esto en conjunción con la forma en que se presenta a Garcilaso en la sección final, el mensaje principal del segundo piso y del museo como un todo parecería ser que la introducción de la cultura europea, en combinación con las tradiciones indígenas preexistentes, produjo la cultura nacional de la moderna nación peruana. Este proceso está simbolizado en cierto sentido con una presentación romantizada de la vida del Inca Garcilaso. Esto también es consistente con una extensa cita en español y en inglés, tomada de un discurso que el escritor Mario Vargas Llosa (quien ha pasado gran parte de su vida en París, Madrid y 


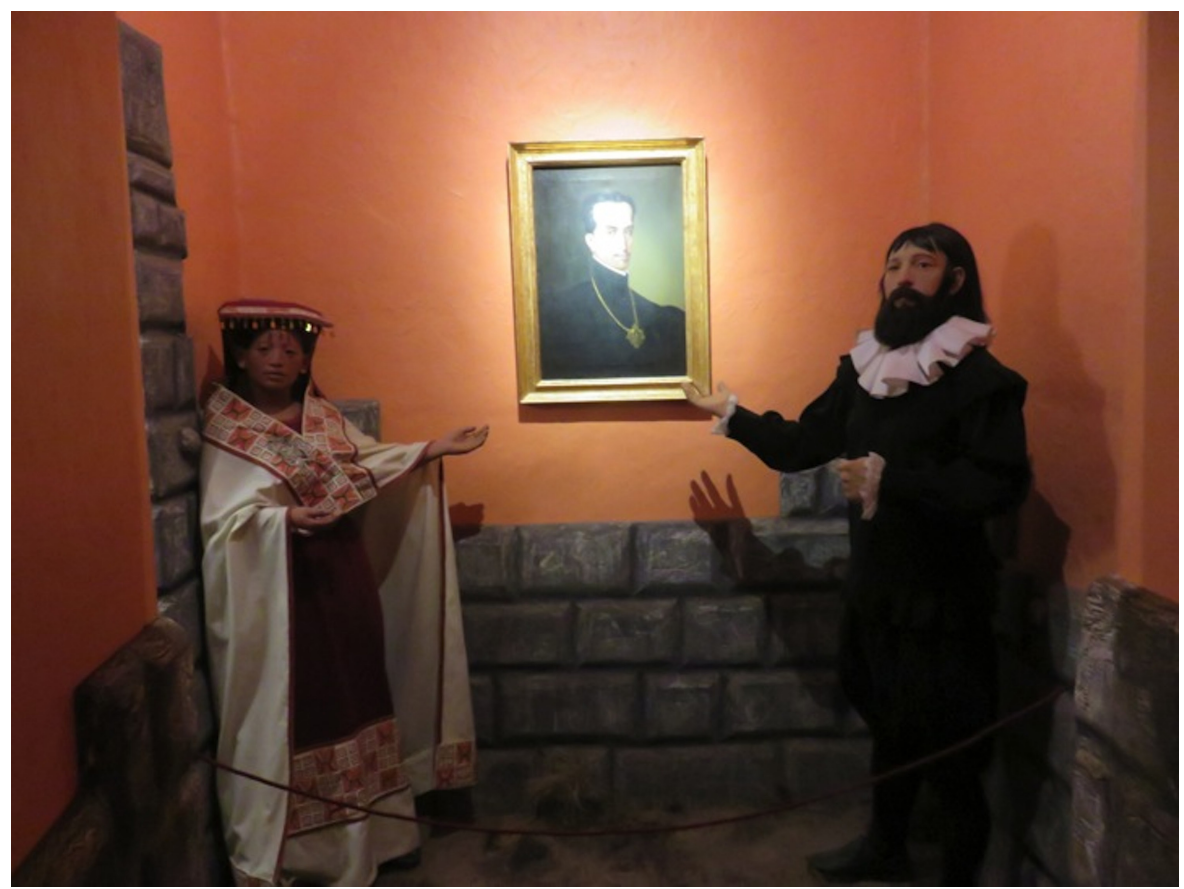

Figura 9. Maniquíes de los padres de Garcilaso de la Vega a ambos lados de un retrato del célebre autor mestizo, Museo Histórico Regional. Foto de Richard Burger.

Mannequins of the parents of Garcilaso de la Vega flanking a portrait of the celebrated Cusqueño author, Museo Histórico Regional. Photo by Richard Burger.

Londres) diera con respecto a la importancia de los museos. Son pocas las personalidades modernas que encarnan el ideal de la identidad nacional mestiza del Perú con tanta claridad como este autor.

Al mismo tiempo, el Museo Histórico describe su objetivo en su página web como "fortalecer la identidad peruana hasta el punto que no hay extranjero que no deje de mostrar sorpresa y respeto por su historia". Resulta significativo que la meta explícita sea reafirmar la identidad peruana antes que la cuzqueña, lo que no resulta sorprendente en un museo administrado y financiado por el Estado peruano. Pero incluso así, la mayor parte del museo tiene un eje cuscocéntrico. El énfasis que la declaración de objetivos pone en los visitantes extranjeros, ayuda a explicar la atención dada a los textos y subtítulos de video en inglés, así como el cuidado que se ha tenido para alcanzar un nivel de calidad museográfica comparable con el que encontramos en países más desarrollados.

La ampliación del museo con nuevas galerías dedicadas a la época preincaica y la introducción de la galería dedicada a Tupac Amaru II minan la coherencia del mensaje original del museo y, probablemente, se les entiende mejor como una expresión de la visión personal de una ambiciosa ex directora que, debe señalarse, no era originaria de Cusco.

\section{Museo de Arte Precolombino (MAP)}

En 2003 el Museo Larco, el más popular de Lima, abrió una sede en el convento de Santa Clara, construcción del siglo XVI para las hijas huérfanas de los conquistadores españoles (Figura 10). En el siglo XVII el edificio pasó a ser propiedad de don Luis Jerónimo de Cabrera y la Cerda y su esposa doña Isabel Tordoya y Bazán. El marcado incremento de los visitantes al Cusco y el tiempo limitado que muchos turistas extranjeros pasan en Lima, probablemente explican la expansión del Museo Larco, algo que no tenía precedentes en el Perú. A diferencia de los dos museos ya examinados, el Museo de Arte Precolombino (conocido como MAP) es privado y no tiene raíces en Cusco, fuera de su sede histórica: quienes lo planearon, sus administradores y colecciones, provinieron todos de Lima. Los objetos exhibidos provienen de las principales culturas prehispánicas de todo el Perú y la selección de las piezas fue hecha por dos limeños, Fernando de Syszlo, célebre pintor, y Cecilia Bakula, historiadora. También se distingue de los otros tres museos aquí descritos porque una justificación central de su creación fue la idea de ganar dinero aprovechando la alta demanda del turismo en Cusco. 


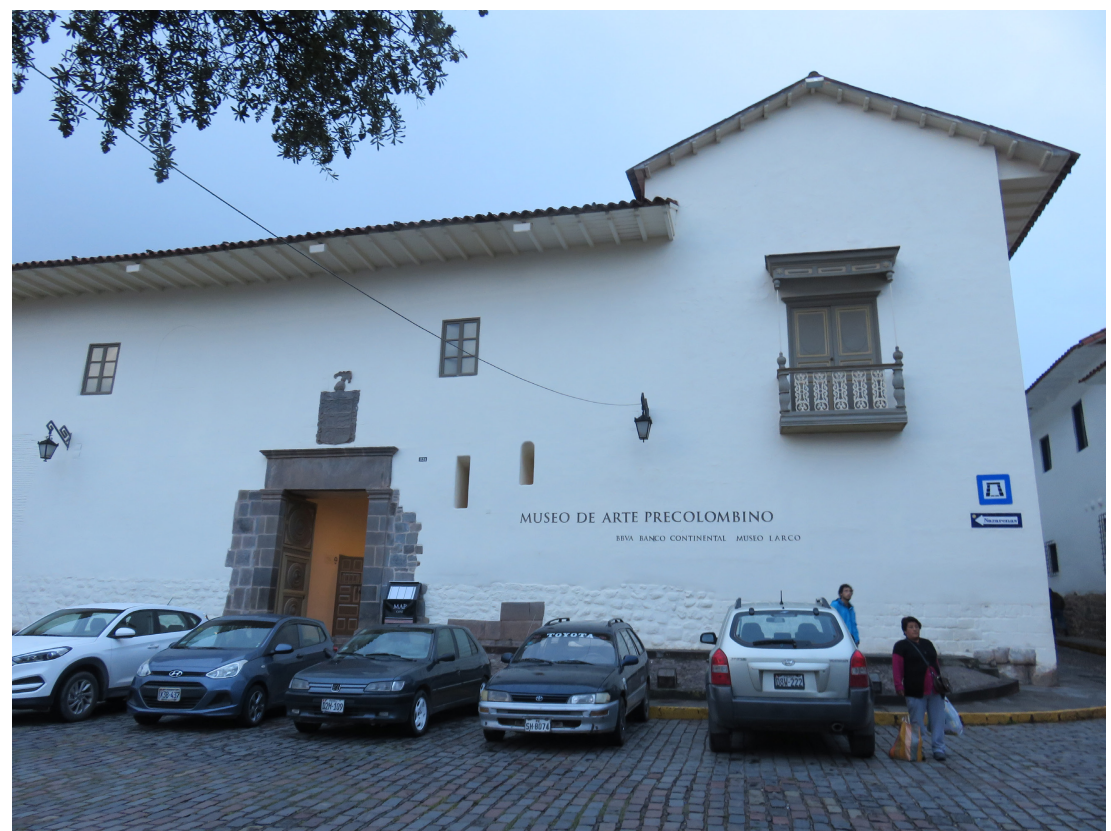

Figura 10. Fachada del Museo de Arte Prelombino (MAP), Casa Cabrera. Foto de Richard Burger.

Exterior of the Museo de Arte Precolombino (MAP) Casa Cabrera. Photo by Richard Burger.

La naturaleza privada del MAP queda inmediatamente en evidencia al ingresar al local, gracias al logo de un banco y de una compañía aseguradora que decoran la entrada (el Banco Continental y BVA Continente, respectivamente). El museo se presenta a sí mismo sin remordimiento alguno como un museo de arte y renuncia conscientemente a las perspectivas arqueológica, antropológica e histórica que predominan en los dos museos que ya hemos analizado. Esto se refleja en la decisión de emplear un marco cronológico, desconocido para los arqueólogos profesionales en el Perú, que comprende cuatro periodos: Formativo (1250 AC-1 DC), Clásico (1-800 DC), Transicional (800-1300 DC) e Imperial (1300-1532 DC).

En lugar de intentar situar los objetos dentro de su contexto cultural e histórico, los paneles explicativos se concentran en las propiedades estéticas y técnicas de los objetos, así como en la respuesta emotiva que se supone produce en los visitantes. Un tema omnipresente es que el arte peruano prehispánico es de clase mundial, y que forma una parte valorada del corpus tradicionalmente conocido como arte precolombino o arte primitivo. El MAP está repleto de testimonios acerca del valor del arte no occidental (o primitivo) de artistas europeos célebres como Paul Gauguin, Henri Matisse, Paul Klee, Vasili Kandinsky, Henry Moore y Georges Braque, los cuales lucen sobre las paredes. Por ejemplo, se cita a Kandinsky, quien dijo que "Nuestra simpatía y nuestro respeto espiritual se vuelven hacia los primitivos porque como nosotros, esos artistas buscan expresar en sus obras tan solo verdades interiores, renunciando, en consecuencia a todas las formas de distracción del entorno".

Tales declaraciones sirven como una justificación cargada de autoridad, que permite tratar como arte a las antigüedades precolombinas del Perú cuidadosamente seleccionadas que se encuentran en el MAP. Como el valor del gran arte es trascendente, no hay necesidad alguna de contextualizar las piezas (Silverman 2006). En efecto, semejante enfoque simplemente alejaría la atención de sus cualidades estéticas.

En este espíritu se exhibe a los objetos en vitrinas exquisitamente diseñadas, iluminadas con luces dramáticas, cuyo estilo recuerda en muchos sentidos al de las elegantes joyerías de Manhattan o París, como Cartier o Tiffany's (Figura 11). Los textos que acompañan a los objetos son poéticos y emotivos. Por ejemplo, un tazón monocromo chancay de color crema (Figura 12), que muestra a dos ollas apiladas, es descrito del siguiente modo:

La simpleza de las formas y el acabado monocromático promueven entre sí una sutil complicidad. Nada es producto de la casualidad; es el artista de manos expertas y alma sensible, quien logra trasmitir -traspasando la barrera del tiempo- la armonía y el equilibrio que deben estar presentes en la obra de arte. 


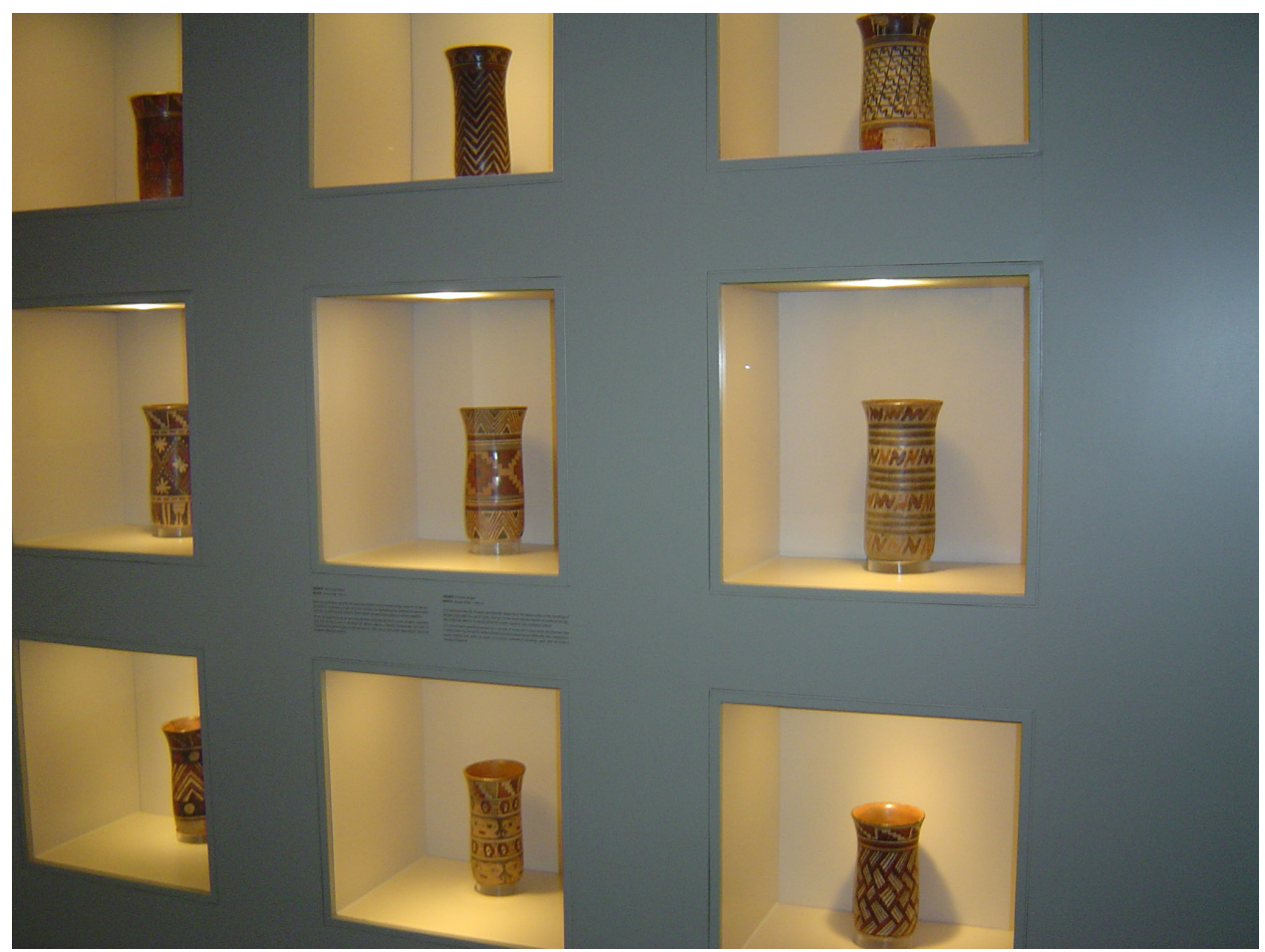

Figura 11. Exhibición de cerámica de estilo Nasca, MAP. Foto de Helaine Silverman. Exhibition of ceramics in the Nasca style, MAP. Photo by Helaine Silverman.

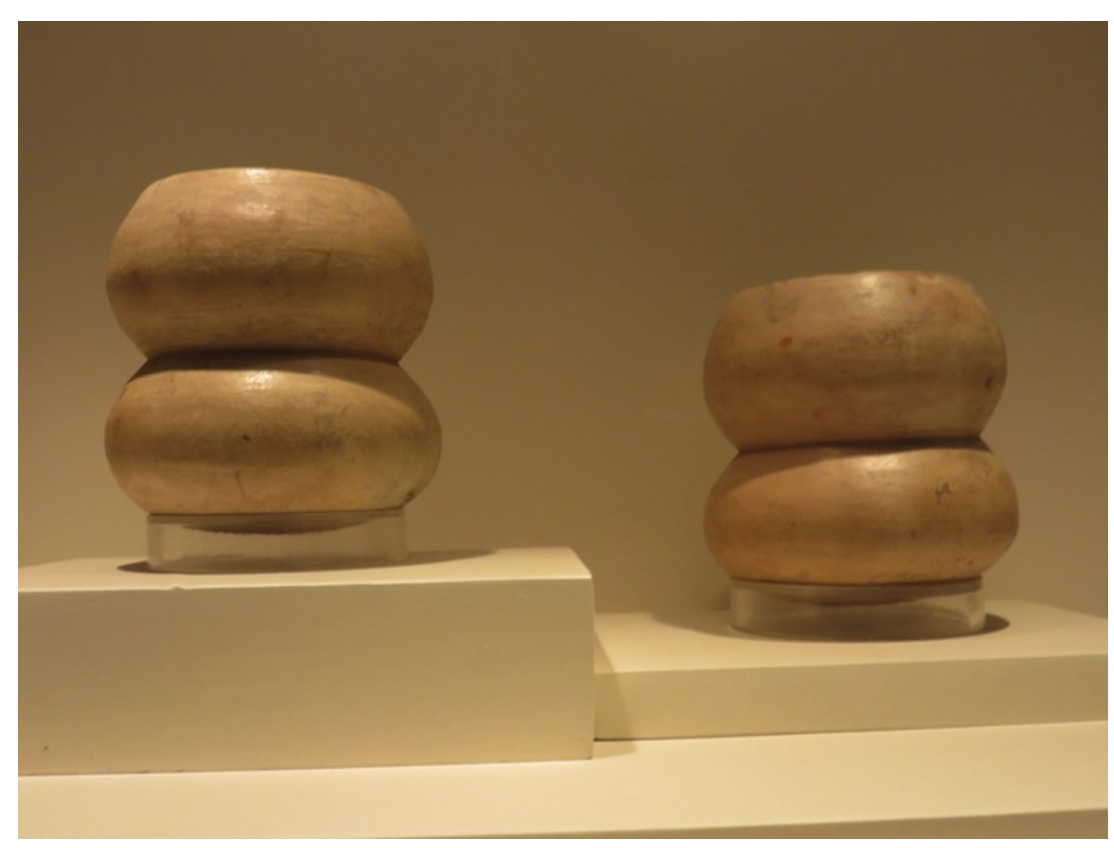

Figura 12. Cerámica geométrica de estilo Chancay, MAP. Foto de Helaine Silverman. Geometric ceramic vessels in the Chancay style, MAP. Photo by Helaine Silverman. 
Las leyendas se ofrecen en tres lenguas, español, francés e inglés. De este modo, el MAP parece estar dirigido hacia un público internacional antes que local y, si bien el museo se encuentra en el centro histórico del Cusco, no hay evidencia alguna de una perspectiva cuscocéntrica. Los objetos exhibidos provienen fundamentalmente del saqueo de yacimientos arqueológicos, cuyo botín fue comprado y conservado por coleccionistas acaudalados como Rafael Larco Hoyle, el fundador del Museo Larco. Solamente un pequeño porcentaje de las piezas es del Cusco.

El MAP está organizado por culturas y por materiales y las salas están dedicadas a los más conocidos estilos artísticos del Perú prehispánico: Formativo, Nasca, Mochica, Huari, Chimú-Chancay e Inca. Significativamente y no obstante el nombre del museo, la evolución cronológica a lo largo de las culturas precolombinas del Perú culmina en una larga galería dedicada exclusivamente al arte católico del virreinato, dominada por grandes pinturas al óleo de santos producidas originalmente para iglesias y capillas (Figura 13). A los espacios dedicados a las culturas precolombinas les siguen galerías dedicadas a cuatro clases de objetos: madera, concha, plata y oro. Estas dos últimas salas lucen joyas y otros objetos metálicos que se han restaurado y pulido hasta alcanzar un brillo deslumbrante, reforzando así la visión hispana del Perú como una fuente de metales preciosos y otras riquezas.

El lector tal vez haya advertido en las descripciones de los dos museos anteriores la ausencia de toda mención de tiendas de souvenirs o restaurantes. A diferencia de ellos, antes de terminar la visita al MAP es necesario pasar por tres tiendas de souvenirs del museo: Alpaca 111 (una lujosa tienda que vende ropas de marca hechas con la fina fibra de alpaca), H. Stern (una joyería exclusiva con sede central en Brasil con piezas de oro y gemas) y la tienda del Museo Larco que vende réplicas de gran calidad de objetos precolombinos y artesanías peruanas. En el patio colonial cercano a estas tiendas se alza una moderna edificación rectangular de vidrio diseñada en un estilo minimalista incompatible con la arquitectura colonial que la rodea. Esta estructura anómala alberga un restaurante gourmet que sirve comidas que cuestan más de lo que la mayoría de los cusqueños gana en una semana.

La diferencia entre el MAP y los demás museos no podría ser más marcada. Sus metas son financieras antes que educativas, y sus raíces intelectuales se encuentran en las artes antes que en las ciencias antropológicas e históricas. Aunque no expresa ninguna agenda política, su mensaje es inherentemente conservador y está diseñado para alinear al museo con el mundo

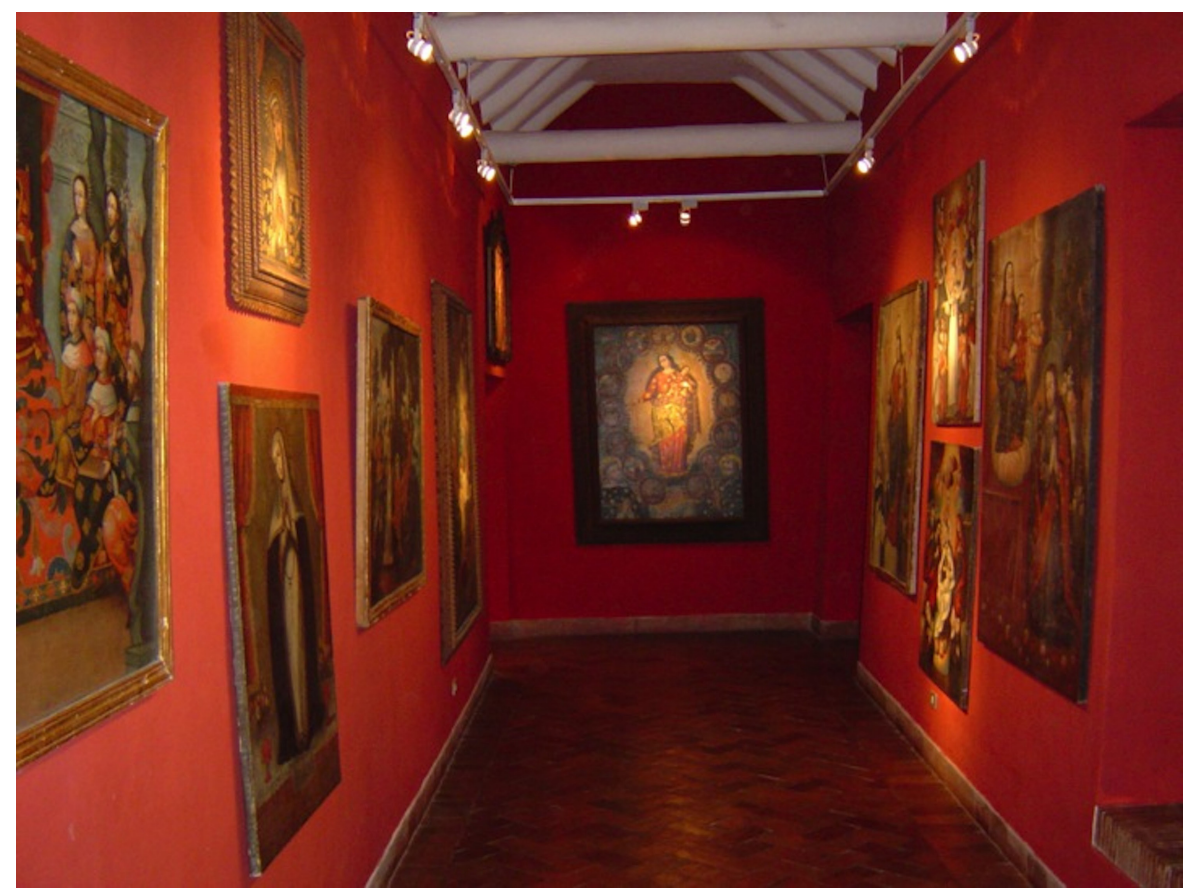

Figura 13. Exhibición de pinturas religiosas coloniales peruanas, MAP. Foto de Helaine Silverman.

Exhibition of colonial religious paintings from Cuzco, MAP. Photo by Helaine Silverman. 
cosmopolita de la élite de los coleccionistas de arte, los gourmets y los consumidores de joyas y ropas exclusivas. El estilo de su museografía es consistente con esta narrativa y lo vincula con los recientes procesos que han tenido lugar en el mundo de los museos internacionales, como el Musée du Quai Branly en París. En el MAP no hay ninguna imagen o representación de humanos vivos. No se propone vínculo alguno entre los objetos exhibidos y las poblaciones modernas del Cusco (o del Perú). Sin embargo, el museo sí expresa elocuentemente las aspiraciones que el Perú moderno tiene de participar en el sistema global de la cultura de élite cosmopolita.

\section{El Museo Machu Picchu, Casa Concha}

El Museo Machu Picchu se fundó en 2011, como parte de las celebraciones por el centenario del "descubrimiento científico" que Hiram Bingham hiciera de Machu Picchu. Su creación fue un resultado de las negociaciones diplomáticas llevadas a cabo entre la Universidad de Yale, la UNSAAC y el gobierno peruano(Falcón 2013). Esto produjo tres memorándums de entendimiento (MDE): uno entre la Universidad de Yale y la UNSAAC, otro entre la Universidad de Yale y el gobierno peruano, y un tercero entre la UNSAAC y el gobierno peruano. Los MDE resolvieron una disputa de una década en torno a las colecciones que la Expedición Científica de Yale de 1912 excavara en Machu Picchu. Bingham llevó los materiales al Peabody Museum of Natural History de la Universidad de Yale con el permiso del gobierno peruano pero este último sostuvo, durante el mandato del presidente Alejandro Toledo, que después de casi un siglo debieran retornar a Perú. El conflicto político y legal fue resuelto diplomáticamente dentro del marco de una colaboración educativa de largo plazo entre Yale y la UNSAAC (Salazar y Burger 2016). La creación de un museo en el Cusco para que guardara la colección Bingham de Machu Picchu fue un elemento central del acuerdo. En conformidad con los MDE, la UNSAAC aceptó proporcionar un local con la infraestructura necesaria para el establecimiento del museo, en tanto que Yale se encargaba del diseño, la producción y la instalación de la exhibición. Todos los materiales de Machu Picchu fueron devueltos por Yale al Cusco en tres cargamentos y su propiedad legal fue transferida al gobierno peruano, haciendo la UNSAAC las veces de su administrador durante los siguientes cincuenta años.

La Casa Concha, una hermosa mansión colonial del siglo XVIII que fuera construida por don Diego Concha Salvatierra, fue elegida como sede del museo por Víctor Raúl Aguilar, el rector de la UNSAAC (Figura 14). En 2001 el inmueble fue entregado a la universidad por el presidente cuzqueño Valentín Paniagua. Esta elección resultó particularmente idónea puesto que la Casa Concha se levanta sobre Puka Marka, el palacio de Túpac Inca Yupanqui, hijo de quien se cree fue responsable de la construcción de Machu Picchu: Pachacuti. La Casa Concha tiene muros incaicos visibles así como pinturas murales coloniales y chimeneas de piedra del siglo XIX, por lo que su visita permite ver toda la historia arquitectónica del Cusco. Al igual que los otros tres museos, las exhibiciones llenan las grandes habitaciones en los dos pisos que rodean al patio principal.

Los costos de la instalación del Museo Machu Picchu fueron cubiertos conjuntamente por Yale y la UNSAAC. La principal motivación fue crear un entorno que preservará y conservará las colecciones de Machu Picchu, además de hacerlas accesibles para el público en general mediante exhibiciones. Afortunadamente, las colecciones ya habían servido de base para una exhibición itinerante mostrada en siete sedes en los Estados Unidos de América entre 2003 y 2006 (Burger y Salazar 2004). Curada por los arqueólogos Richard Burger y Lucy Salazar, de Yale, esta muestra incorporaba los resultados de las investigaciones realizadas sobre los artefactos de Machu Picchu durante las décadas previas. Por motivos políticos, el museo debía inaugurarse antes de finales de 2011, mientras el presidente Alan García aún estuviese al mando, lo que se logró adaptando la exhibición itinerante a una nueva sede y público en Cusco. Todos los contenidos fueron hechos plenamente bilingües (inglés y español). En la exhibición itinerante de los E.U.A. se sumaron artefactos de oro, plata y otros materiales que fueron prestados por museos estadounidenses y europeos (Burger y Salazar 2004). No fue factible incluir estos materiales ajenos pero el Museo Machu Picchu logró conseguir el préstamo de artefactos incaicos similares por parte del Museo Inka, también administrado por la UNSAAC. Cayo García, ex decano de la escuela de arquitectura de esta universidad, estuvo a cargo de la restauración de la Casa Concha y colaboró con Burger y Salazar en el diseño e instalación de la exhibición inaugural.

El enfoque del Museo Machu Picchu es más restringido que el de los otros tres museos analizados. Se interesa mayormente por un solo yacimiento arqueológico y su lugar dentro del contexto más amplio de la cultura y la sociedad incaicas. Como sería de esperar, dados los antecedentes de los curadores, la perspectiva ofrecida se deriva de la arqueología y la antropología. La exhibición inicia con un breve video que ofrece al visitante el contexto necesario para comprender las salas que siguen. Se sitúa a los incas en el tiempo y en el espacio, y se presentan los antecedentes de las investigaciones científicas de Bingham empleando recreaciones históricas. Las dos primeras salas están dedicadas a los trabajos 


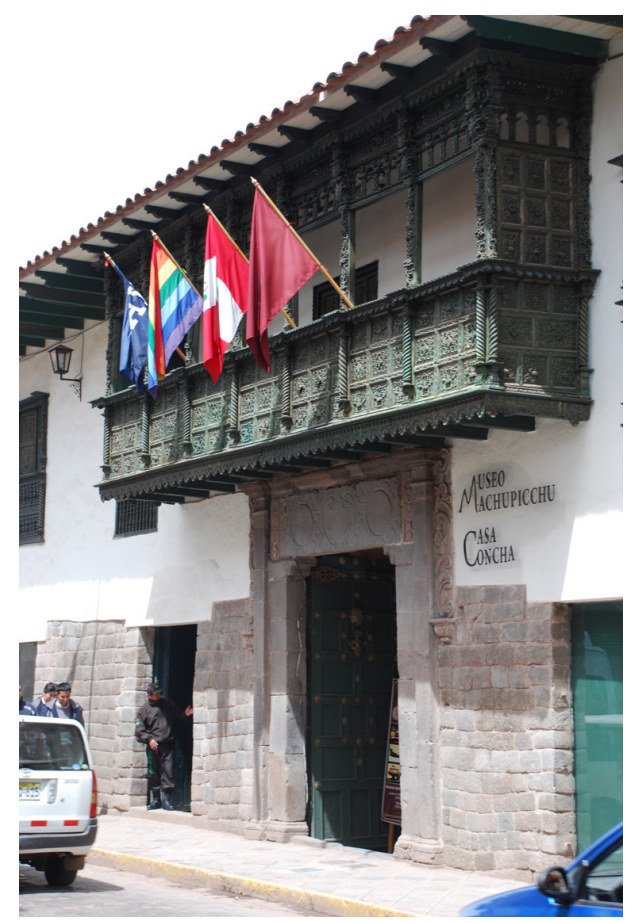

Figura 14. Fachada del Museo Machu Picchu, Casa Concha. Foto de Richard Burger.

Exterior of the Museo Machu Picchu, Casa Concha. Photo by Richard Burger.

arqueológicos que Bingham llevó a cabo en Machu Picchu, figurando un dibujo que el propio explorador hiciera del templo principal del sitio el día de su primera visita, una plomada empleada en las excavaciones de 1912 y una carta de apoyo a Bingham escrita por Augusto B. Leguía, presidente del Perú en ese entonces. Un diorama de tamaño natural en tonos sepias presenta a Bingham fotografiando la excavación de una caverna mortuoria y los objetos mismos recuperados en este contexto arqueológico se exhiben en la vitrina vecina (Figura 15). La siguiente galería muestra fotografías históricas, muchas de ellas tomadas por Bingham, algunas de las cuales fueron coloreadas a mano, asî como el mapa detallado de Machu Picchu preparado por la expedición de 1912. Una vitrina central en esta sala contiene publicaciones que tuvieron su origen en las tres expediciones científicas de Yale.

Las dos salas descritas contextualizan el trabajo realizado por Bingham dentro de la historia de la arqueología peruana, enfatizando tanto su naturaleza pionera como el marco científico dentro del cual se le llevó a cabo, minando las caracterizaciones que lo consideran como un diletante o saqueador y que han circulado con fines políticos. Estas salas también ayudan al visitante a que aprecie la importancia histórica singular de las colecciones que verá exhibidas en el resto del museo (Burger y Salazar 2013).
Después se muestra una maqueta de Machu Picchu acompañada de un video en que los dos curadores explican su función como un palacio o residencia rural usada por la nobleza incaica durante los meses de invierno (Figura 16). Unas luces programadas iluminan las partes de las que se va hablando, para así brindar al visitante una idea de las actividades que se llevaban a cabo en los distintos sectores del sitio. $\mathrm{La}$ presentación se enriquece con textos en las paredes que indican el papel que la fotografía aérea y las imágenes satelitales tienen en el análisis de este yacimiento, y una fotografía panorámica gigante del paisaje que le rodea, del tamaño de una pared, permite apreciar mejor la belleza natural del lugar.

El énfasis que el museo hace en concebir a Machu Picchu como un sitio en funcionamiento, con actividades inteligibles que reflejan los elementos fundamentales de la cultura Inca, está en consonancia con las investigaciones y la orientación de los curadores y sus colaboradores (Burger y Salazar 2003, 2012; Salazar 2004, 2007; Salazar y Burger 2004). Esta perspectiva busca proporcionar una alternativa a las presentaciones populares de Machu Picchu como un lugar "místico" y "mágico" (Flores Ochoa 2004). El enfoque antropológico es evidente en la siguiente sala, que muestra artefactos relacionados con la producción de chicha de maíz y textiles, entre los que figuran numerosos piruros (discos 


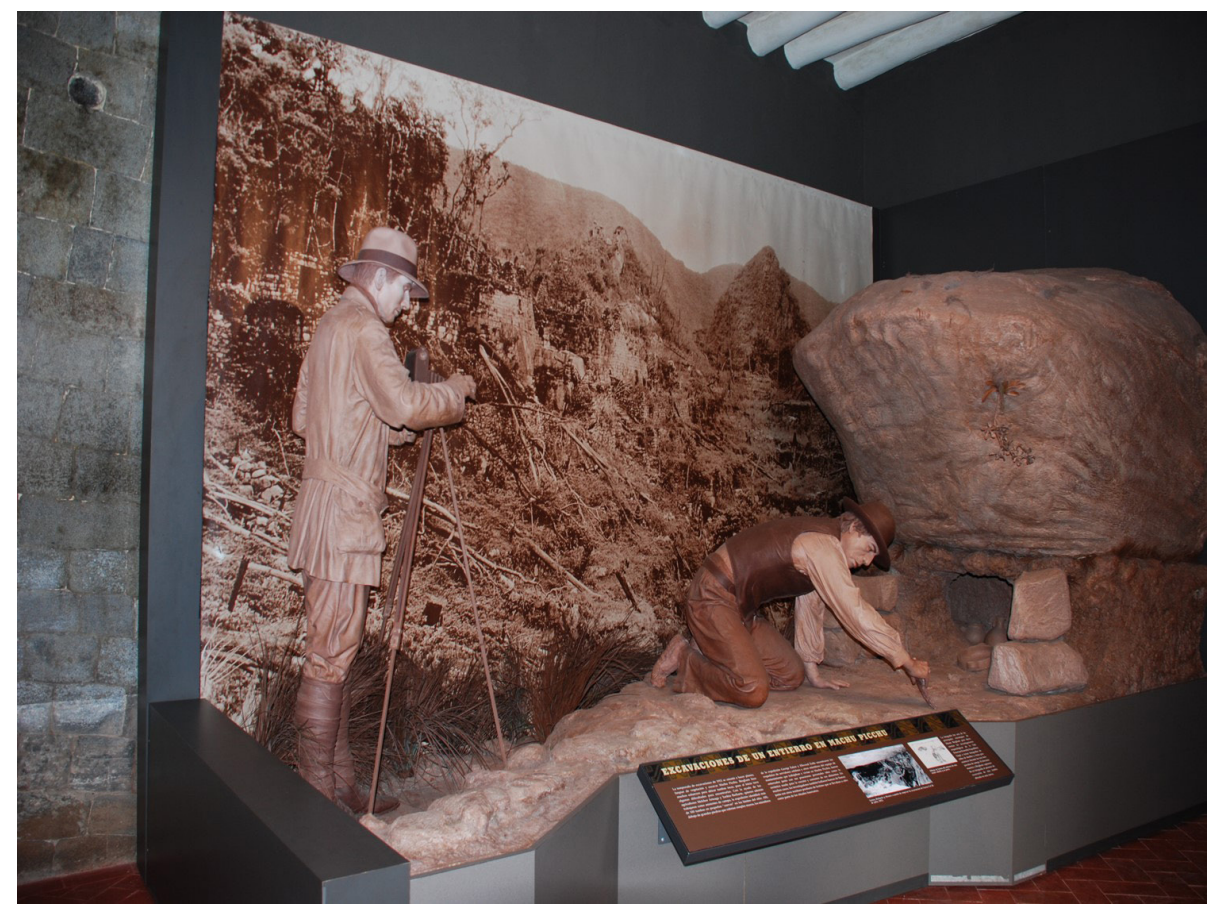

Figura 15. Diorama de Hiaram Bingham III tomando fotografías de una tumba Inca en Machu Picchu en base de fotografías históricas de color sepia, Museo Machu Picchu. Foto de Richard Burger.

Diorama of Hiram Bingham III photographing an Inca tomb in Machu Picchu. It is based on the sepia-colored historical photographs of the 1912 Yale Peruvian Scientific Expedition. Photo by Richard Burger.

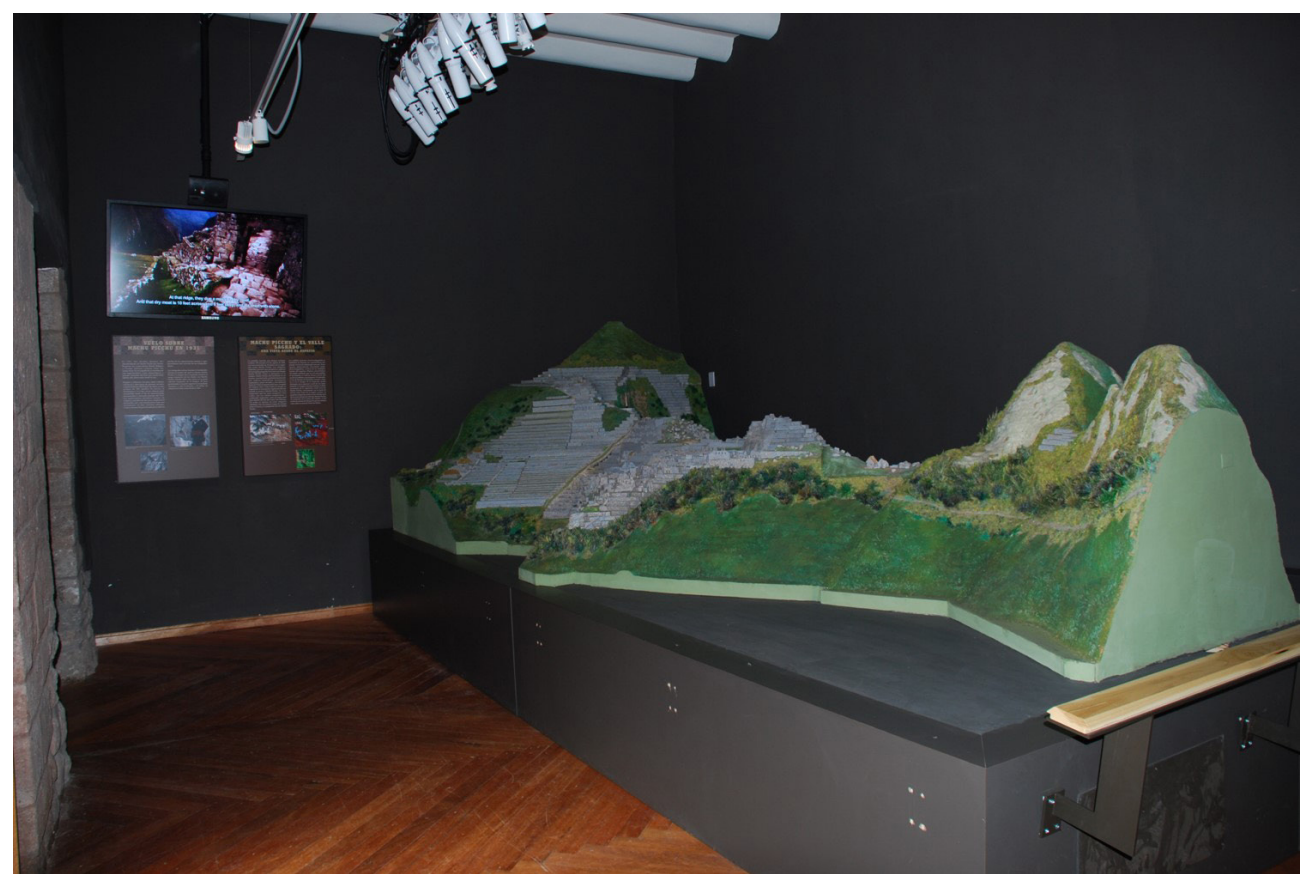

Figura 16. Maqueta masiva de Machu Picchu con videos y gráficos suplementarios. Museo Machu Picchu. Foto de Richard Burger. Large model of Machu Picchu supplemented by videos and graphic texts. Museo Machu Picchu. Photo by Richard Burger. 
de husos) usados para hilar, así como herramientas para tejer hechas con hueso de llama que se recuperaron durante las excavaciones de 1912. Junto a ellos se encuentra una fina túnica incaica $(u n k u)$ perteneciente al Museo Inka, cuyo préstamo fue crucial puesto que ningún textil se ha conservado en el medio ambiente húmedo de Machu Picchu.

Si bien las actividades cotidianas tienen un papel importante en el museo, también se reconoce la relevancia que tuvieron las actividades religiosas dedicándole una vitrina a los artículos rituales, así como un breve video sobre las observaciones astronómicas en Machu Picchu. En él se explica la forma en que los arqueoastrónomos han probado que desde este sitio se observaban tanto el solsticio de invierno como el de verano.

La galería más grande en el segundo piso está dedicada a la vida cotidiana. Aquí se exhiben las vasijas de cerámica usadas para cocinar, almacenar líquidos y servir comida sólida, al igual que herramientas de piedra para preparar los alimentos. También se muestran adornos personales como ornamentos para las orejas, espejos y collares, junto con flautas de hueso, campanas de metal usadas en las danzas y dados de cerámica para apostar. Las puntas y bolas de piedra empleadas para cazar ayudan a completar la imagen de las actividades recreacionales llevadas a cabo en la residencia real. Otro tema que se resalta es la naturaleza cosmopolita de Machu Picchu. Los yanaconas que trabajaron de servidumbres y artesanos eran traídos de todo el Imperio Inca, lo que se ilustra con la exhibición de materiales cerámicos foráneos hallados en las tumbas de los yanacona, excavadas por la expedición de 1912.

En la sala vecina se muestra una de las actividades inesperadas que se realizaban en Machu Picchu: la producción de objetos metálicos. Las evidencias de ello incluyen herramientas para trabajar el metal y productos derivados, como escorias y artefactos de metal incompletos. Una escultura de tamaño natural de un metalurgista ocupado en su labor ayuda a dramatizar este tema. Objetos preciosos de plata, algunos de los cuales fueron prestados por el Museo Inka y otros provenientes de Machu Picchu mismo, sugieren los tipos de adorno de alto estatus que habrían sido utilizados por los miembros de la élite que visitaba la residencia rural.

Al lado de la sala de metalurgia se halla una galería dedicada exclusivamente al estudio científico de las colecciones de Machu Picchu. Diseñada para evocar el entorno de un laboratorio, presenta los resultados de investigaciones realizadas en torno a la dieta de los residentes usando isótopos de carbono; sobre la salud de su población utilizando técnicas paleopatológicas; y sobre los patrones de obtención de obsidiana a larga distancia mediante la activación por neutrones (Figura 17). La naturaleza multicultural del sitio

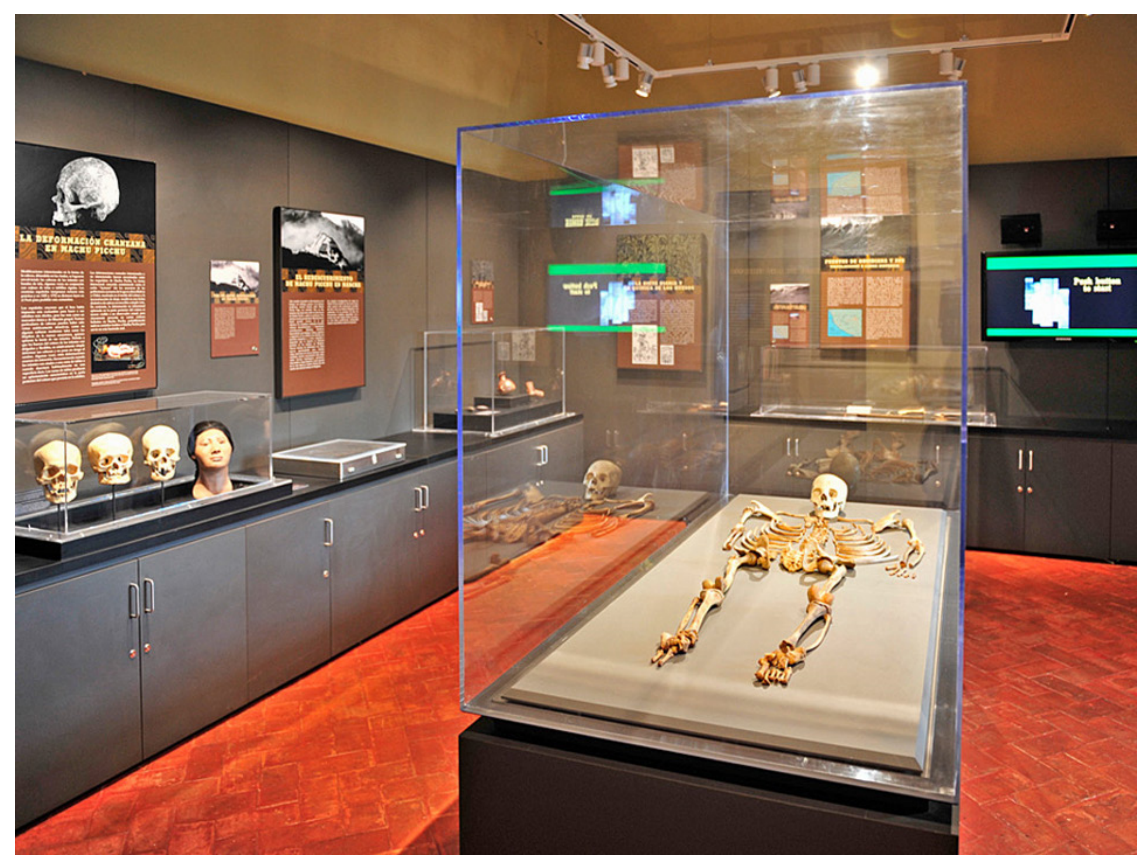

Figura 17. Sala de exhibición semejante a un laboratorio, que muestra análisis científicos, incluyendo un esqueleto bien conservado de Machu Picchu, Museo Machu Picchu. Foto de Richard Burger.

Exhibition gallery evoking the environment of an archaeological laboratory and illustrating the results of scientific analyses, including the study of a well preserved skeleton from Machu Picchu, Museo Machu Picchu. Photo by Richard Burger. 
queda reforzada con un examen de los distintos tipos de deformación craneana documentados, tema traído a la vida con la reconstrucción facial que un antropólogo forense hizo del cráneo de una joven con deformación extrema. Al centro de la sala está el esqueleto de un joven yanacona de Machu Picchu que, al igual que en el Museo Inka, resulta de gran interés para el público cuzqueño, pero que aquí ilustra lo que podemos aprender acerca de la vida y muerte de una persona recurriendo al análisis osteológico. Un breve video en el que se entrevista a algunos de los científicos responsables de estos estudios, deja en claro que fue gracias a las investigaciones arqueológicas que se alcanzó una comprensión más refinada de Machu Picchu (Burger 2004).

La última sala en el segundo piso dedicada a Machu Picchu alberga un interactivo que permite al visitante navegar por el sitio arqueológico y encontrar lugares importantes vinculados a fotografías históricas, además de ofrecer presentaciones en video de investigadores, exposiciones animadas a cargo de Verónica Vizcacha y otros personajes imaginarios de caricatura (Figura 18). El diseño de múltiples niveles de este interactivo, desarrollado por el arqueólogo George Miller, hace eco de muchos de los temas encontrados en las salas previas pero con una técnica museológica que es particularmente popular entre los visitantes jóvenes. Una gran pantalla "esclava" fijada a una de las terminales de computadora, permite que grupos escolares en su conjunto disfruten de esta experiencia.

Una última galería, que se visita antes de la salida, está ocupada por un gran diorama que muestra una escena de la vida cotidiana de la nobleza incaica (Figura 19). A partir de los dibujos del artista colonial Guamán Poma, se muestra al emperador inca siendo atendido por un sirviente mientras consulta a un administrador estatal que sostiene un instrumento de registro con cordeles anudados (quipu). Se puede escuchar un diálogo en quechua cuzqueño entre el emperador (Sapaq Inka) y su funcionario, sobre un fondo de sonidos ambientales naturales grabado en Machu Picchu.

La narrativa principal del Museo Machu Picchu se interrumpe en una sola sala del segundo piso, dedicada a los artefactos incaicos descubiertos en la Casa Concha durante su restauración. Al igual que los muros incas, las coloridas pinturas murales coloniales, las puertas de madera talladas, las elaborados chimeneas, los patios empedrados con mosaicos y la capilla restaurada, esta habitación repleta de tesoros sitúa el inmueble del museo en el contexto de la compleja historia del centro histórico de Cusco.

Como puede deducirse a partir de la descripción anterior, el Museo Machu Picchu difiere de los otros tres museos en varias formas. Su interés por la historia

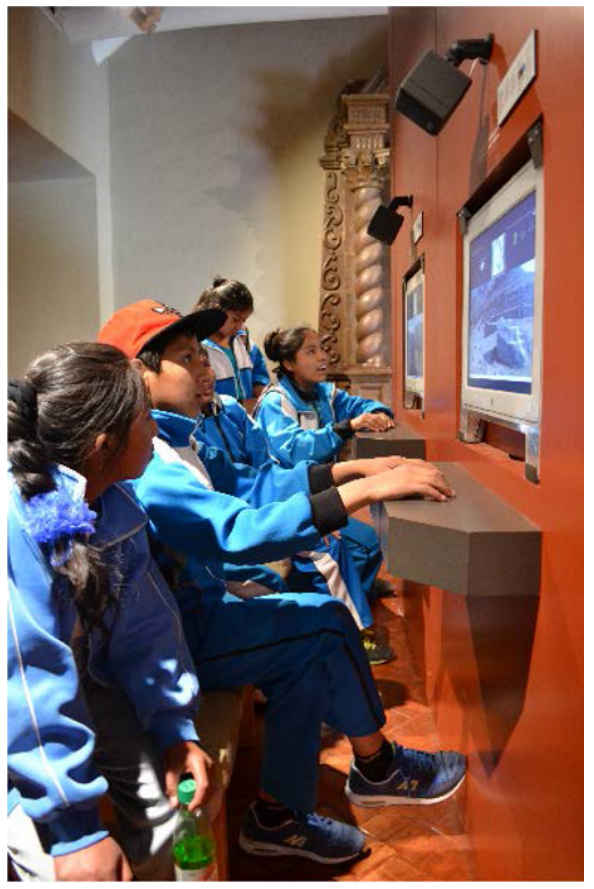

Figura 18. Escolares cuzqueños utilizan el programa interactivo, Museo Machu Picchu. Foto de Richard Burger.

Cusqueño school children using the interactive computer exhibit, Museo Machu Picchu. Photo by Richard Burger.

de la investigación arqueológica y el énfasis que da al estudio arqueológico y de laboratorio es una de sus diferencias. El tipo de técnicas museográficas utilizadas, como los dioramas que emplean todos los recursos disponibles, los programas de computadora interactivos y los numerosos videos bien producidos, superan por mucho a las de las restantes instituciones. Este enfoque museográfico fue posible gracias al respaldo financiero y técnico proveniente de los Estados Unidos, tal como quedó estipulado en el MDE entre Yale y la UNSAAC.

La prominencia de los extranjeros, desde Bingham hasta muchos de los científicos entrevistados, le da un sabor internacional que contrasta con el tono nacionalista del Museo Inka o el Museo Histórico Regional. Esto, claro está, se debe al papel central que la Universidad de Yale tuvo y sigue teniendo en su organización y mantenimiento, lo cual ciertamente disminuirá con el paso del tiempo, a medida que se introduzcan nuevas salas y se efectúen cambios en las ya existentes. Por ejemplo, está programada la apertura de nuevas salas dedicadas a la ecología y la arquitectura inca en 2019 y también introducir textos en quechua además de los que están en inglés y español. Asimismo, se tiene planeado sumar un nuevo eje en torno al papel que tuvieron los peruanos en las excavaciones de 1912, además de las investigaciones que actualmente se están llevando a cabo en Machu Picchu. 


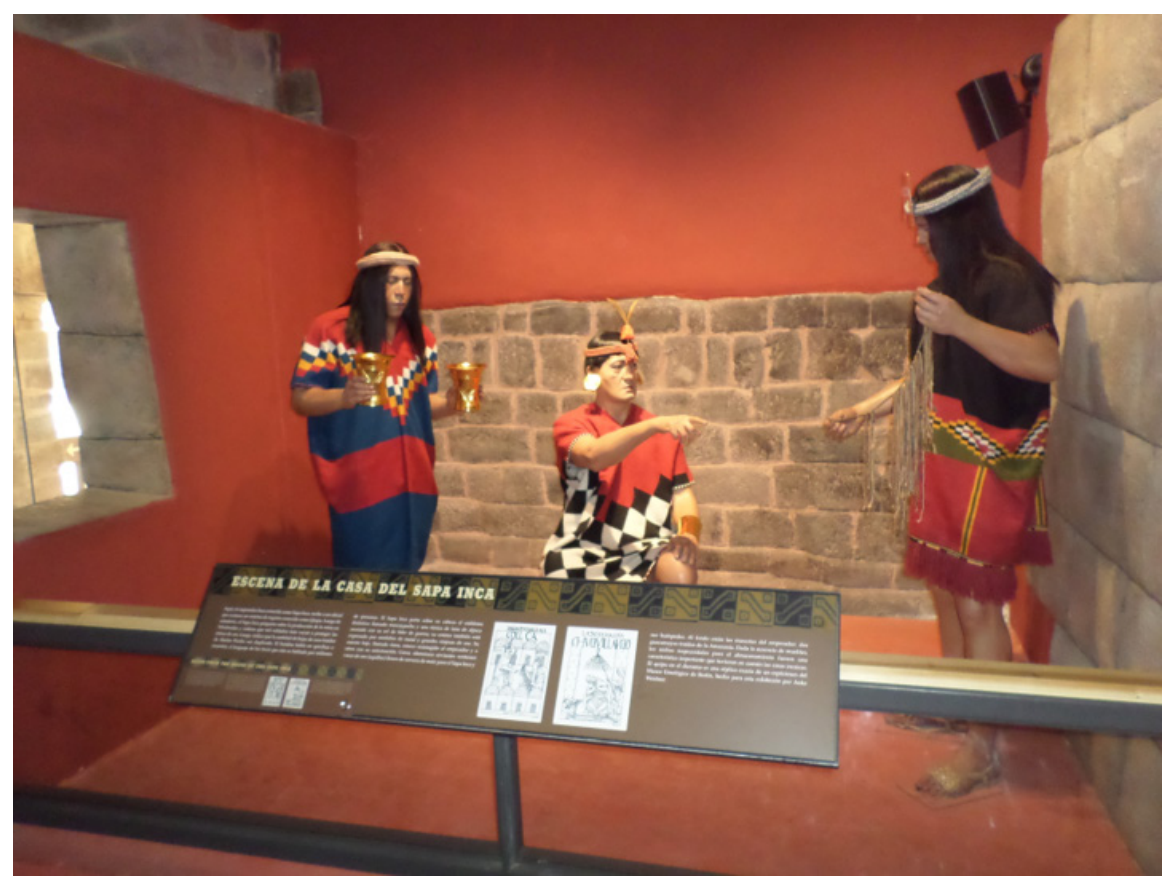

Figura 19. Diorama del Sapa Inca y el séquito de la corte, Museo Machu Picchu. Fotos de Richard Burger.

Diorama of the Sapa Inca and members of his court, Museo Machu Picchu. Photo by Richard Burger.

\section{Discusión}

El estudio de cuatro museos en la ciudad de Cusco ha registrado la diversidad que existe en las narrativas que hemos observado. El contraste entre las narrativas de estos museos puede ser analizado como la expresión de agendas institucionales. Por ejemplo, el guión narrativo del Museo Inka destaca los logros únicos de la civilización Inca y la continuidad de esta tradición cultural en el Cusco moderno, a pesar de los esfuerzos incansables por los invasores españoles y sus descendientes para extinguirlos. Este mensaje es tan relevante para los jóvenes cuzqueños que están en proceso de formar su sentido de identidad como para el resto de peruanos, ya sean de origen costeño o selváticos y/o visitantes extranjeros que llegan a Cusco con una visión cultural y racial, de carácter eurocéntrico de la historia del Perú.

Por el contrario, el Museo Histórico Garcilaso de la Vega promociona la narrativa oficial del Estado peruano donde laidentidad peruana es representada como la fusión de culturas indígenas que se remontan a miles de años, combinado con elementos culturales introducidos desde Europa, Asia y África. Es decir que se ha producido una cultura mestiza, rica y compleja en la que estos diferentes elementos se fusionan de una manera única para producir la moderna cultura peruana. Cabe resaltar que la versión de este proceso que se ilustra en el Museo Histórico no es la narrativa que se hubiera promovido en los años 1960 $\mathrm{o}$ antes, en la que la cultura criolla de base europea fue preponderante. La versión que se visualiza es derivada de los tiempos posteriores al gobierno del Presidente Velasco Alvarado (post-1975) cuando la profundidad y complejidad de la cultura prehispánica peruana adquiere igual o mayor importancia que los desarrollos postconquista. Asimismo, el papel de la resistencia indígena por líderes como Túpac Amaru II noeran resaltados antes del gobierno de Velasco Alvarado. Aunque Garcilaso de la Vega sigue simbolizando la visión mestiza de la identidad peruana, ahora José Gabriel Condorcanqui comparte este rol en los ambientes del Museo Histórico. El mensaje complejo que nos ofrece tanto el Museo Inka, como el Museo Histórico, es igual de relevante para los residentes locales y los visitantes foráneos que intentan entender el Cusco y el Perú, aunque probablemente ambos se entiendan de maneras muy diferentes.

Una tercera narrativa se puede identificar en el Museo Machu Picchu en la Casa Concha, co-patrocinado por la Universidad de Yale y la UNSAAC. El museo se enfoca en el desempeño de la ciencia arqueológica y los estudios históricos en la comprensión de Machu Picchu, el sitio arqueológico más famoso en el Cusco. Asimismo, enfatiza el papel de los investigadores extranjeros y peruanos, al igual que la aplicación de tecnología 
científica; por otro lado, el desarrollo tecnológico en este proceso mediante el uso de audiovisuales, iluminación, computadoras interactivas, etc. Un segundo tema igual de importante, es el reconocimiento histórico de las contribuciones de Hiram Bingham III y la Expedición Peruana de Yale, en los albores del siglo XX, de traer atención a este sitio previamente ignorado. $\mathrm{El}$ respeto mostrado hacia el llamado descubridor científico de Machu Picchu está en un esfuerzo más amplio para contextualizar históricamente esta etapa temprana de la arqueología inca.

El Museo Garcilaso de la Vega puede describirse como un reflejo de una perspectiva nacionalista peruana y el Museo Inka como la promoción de una agenda indigenista de la élite cuzqueña. Asimismo, el Museo Machu Picchu se puede caracterizar como una visión a largo plazo de una ciencia colaborativa internacional o global.

El cuarto y último museo revisado es el Museo de Arte Precolombino (MAP), este presenta también una visión cosmopolita sujeta a la trascendental hipótesis de las cualidades estéticas del arte moderno válida hoy en día. La estética puede ser definida en relación a la teoría de la percepción de belleza o buen gusto; en este caso por la apariencia visual de objetos que se denominan "bellos". Aunque a menudo el término "bello" está en constante debate, ya que belleza está en "el ojo del espectador", en el MAP esta perspectiva vinculada a las élites mundiales que se refleja por museos de arte y colecciones privadas. Curiosamente, aunque el MAP es producto del museo privado Rafael Larco y los objetos en la exhibición del MAP en Cusco provienen de esta colección, la perspectiva basada en la historia del arte del MAP es disímil de su institución matriz en Lima, donde se expone la mayor colección de "tesoros" precolombinos para presentar una narrativa históricocultural de los logros del pasado peruano y su relación con la geografía única de Perú.

Sin embargo, al considerar estas cuatro narrativas contrastantes nada más que como propaganda finamente velada de las instituciones responsables, el resultado no es enteramente satisfactorio. Cada uno de estos museos tienen un elemento de la verdad y nos ofrecen sus propias ideas sobre el pasado inca y el Cusco. Tal vez las diferentes narrativas de estos museos podrían ser provechosamente concebidas como la expresión de diferentes weltanshauungs (cosmovisiones). Naturalmente, la diferencia en estas cosmovisiones puede, en última instancia, provenir de los diferentes orígenes (raza, clase, nacionalidad, género, educación, etc.) de los individuos responsables de la creación y renovación de estas instituciones y, en un sentido general, las narrativas contrastantes posiblemente representan las perspectivas de las instituciones que los apoyan. No obstante, ¿cuánto control o participación de los directores o administradores de las instituciones patrocinadoras (es decir, el gobierno peruano, la Universidad de Cusco, la Universidad de Yale o el Museo Larco) en realidad tienen? Al tratar las diferencias entre los cuatro museos como expresiones de diferentes weltanshauungs, se está reconociendo tanto la sinceridad de los creadores como la posibilidad, o incluso la probabilidad, de que haya valor en abundancia, quizás en todas, de las exposiciones resultantes. A fin de lograr un mejor análisis es clave considerar los contrastes significativos en las visiones que están siendo presentadas, en lugar de analizar los errores o limitaciones de las mismas.

La presencia de múltiples narrativas museísticas, incluso en una pequeña área como el Cusco, no es de ninguna manera única. Esto se debe a la innegable diversidad de la zona. Un excelente ejemplo de este proceso en otro lugar, puede encontrarse en la descripción de Kark y Perry (2012) de museos en Israel.

$\mathrm{Si}$ el enfoque se desplaza de las instituciones patrocinadoras a los curadores responsables de las exposiciones, se pueden obtener algunas ideas adicionales. En el caso del Museo Inka, las personas responsables fueron antropólogos y arqueólogos asociados, como el Dr. Jorge Flores Ochoa, con esta universidad regional. La investigación se ha centrado en la explotación y opresión de las poblaciones indígenas del Cusco; primero por la invasión española, luego por sus descendientes criollos, y finalmente por las élites mestizas. Los herederos de los incas, y otros grupos étnicos indígenas, han sido a menudo marginados o incluso omitidos de las narrativas de la historia peruana; por lo cual, el Museo Inka busca reivindicar esta mayoría indígena convirtiéndolos en el centro del discurso histórico y de este modo los conecta con los impresionantes logros del Imperio Inca.

La narrativa del Museo Histórico refleja la ideología nacional ampliamente aceptada de que la nación peruana es el producto de la mezcla de muchas culturas durante miles de años. Las exhibiciones fueron producidas por museógrafos (algunos no cusqueños), como Ana María Gálvez, con base en la investigación histórica y experiencia como funcionarios del Ministerio de Cultura del Perú. La presentación de este complejo proceso histórico en el Museo Histórico puede parecer en desacuerdo con la búsqueda de la cultura indígena prístina deseada por muchos viajeros foráneos; sin embargo, es fundamental para entender al Perú urbano contemporáneo, ya sea en Cusco o Lima.

Finalmente, la narrativa del MAP fue una creación de historiadores de arte con experiencia en los museos de arte de Lima y otros. Su labor ofrece un elocuente recordatorio de que el Perú es parte del siglo XXI a nivel mundial, uno profundamente transformado por la globalización. Sus curadores provienen de Lima y los comentarios de artistas europeos y limeños como 
Paul Klee y Fernando de Syzlo ofrecen otra visión del mundo muy distinta que la del mundo de antropólogos, arqueólogos e historiadores.

Los cuatro museos analizados en el Cusco son el producto de estudiosos especializados de las diferentes nacionalidades, formaciones y especialidades. Un crítico anónimo de este ensayo preguntó: “¿en qué medida la población local, especialmente la indígena, es capaz de identificar o relacionarse a estos cuatro discursos contrastantes?". Esta pregunta permanece abierta. Sin la presencia de técnicas museográficas, tales como encuestas de visitantes y grupos de enfoque, es imposible saber e inútil especular. Mientras los cuatro museos intentan influenciar a visitantes de diversos contextos culturales y económicos, cada uno en su manera, el impacto sobre la población permanece desconocido.

Agradecimientos: Este manuscrito ha sido traducido por Javier Flores-Espinoza y Lucy C. Salazar.

\section{Referencias Citadas}

Bauer, B.S. 2004. Ancient Cuzco: Heartland of the Incas. University of Texas Press, Austin.

Burger, R.L. 2004. Scientific insights into daily life at Machu Picchu. En Machu Picchu: Unveiling the Mystery of the Incas, editado por R.L. Burger y L.C. Salazar, pp. 85-106. Yale University Press, New Haven.

Burger, R.L. y L.C. Salazar 2011. Understanding Machu Picchu through the analysis of archaeological collections recovered by the Yale Peruvian Scientific Collection of 1912. En The Machu Picchu Catalogue, pp. 31-39 (edición bilingüe). Embajada de los EE.UU, Lima.

Burger, R.L. y L.C. Salazar 2013. Hiram Bingham III and Machu Picchu: Contextualizing the scientific discovery and its protagonist. En Antiguo Perú: Los Reinos del Sol y de la Luna, editado por V. Pimentel, pp. 28-33. Montreal Museum of Fine Arts, Montreal.,1333.

Falcón Huayta, V. 2013. El Museo Machu Picchu de 1a Casa Concha, Cuzco. Revista Haucaypata. Investigaciones Arqueológicas del Tahuantinsuyo 7:6-21.

Flores Ochoa, J.A. 1990. Inkanismo, resistencia, y continuidad cuzqueños. En El Cuzco: Resistencia y Continuidad, editado por J. Flores Ochoa, pp. 9-14. Centro de Estudios Andinos, Cusco.

Flores Ochoa, J.A. 2005a. Contemporary significance of Machu Picchu. En Unveiling the Mystery of the Incas, editado por R.L. Burger y L.C. Burger, pp. 109-125. Yale University Press, New Haven.

Flores Ochoa, J.A. 2005b. El Centro del Universo Andino. Municipalidad del Cusco, Cusco.

Flores Ochoa, J., E. Kuon Arce y R. Samanez Argumedo 1998. Qeros. Arte Inka en Vasos Ceremoniales. Banco de Crédito del Perú, Lima.
Kark, R. y N. Perry 2012. Museums and multiculturalism in Israel. Themes in Israeli Geography (número especial de Horizons in Geography) 79-80:88-99.

Salazar, L.C. 2004. Machu Picchu: Mysterious royal estate in the cloud forest. En Machu Picchu: Unveiling the Mystery of the Incas, editado por R.L. Burger y L.C. Salazar, pp. 21-47. Yale University Press, New Haven.

Salazar, L.C. 2007. Machu Picchu's silent majority: A consideration of the Inca cemeteries. En Variations in the Expression of Inca Power, editado por R.L. Burger, R. Matos y C. Morris, pp. 165-184. Dumbarton Oaks, Washington, D.C.

Salazar, L.C. y R.L. Burger 2004. The lifestyle of the rich and famous: luxury and daily life in the households of the Machu Picchu elite. En Palaces of the Ancient New World: Form, Function And Meaning, editado por S. Evans y J. Pillsbury, pp. 325-357. Dumbarton Oaks, Washington, D.C.

Salazar, L.C. y R.L. Burger 2016. The Machu Picchu solution: A new approach to cultural patrimony disputes. En Finding Solutions For Protecting And Sharing Archaeological Heritage Resources, editado por A.P. Underhill y L.C. Salazar, pp. 87-102. Springer Press, New York.

Silverman, H. 2002. Touring ancient times: the present and presented past in contemporary Peru. American Anthropologist 104 (3):881-902.

Silverman, H. 2006. The historic district of Cusco as an open-air site museum. En Archaeological Site Museums, editado por H. Silverman, pp. 159-183. University of Florida Press, Gainesville.

Silverman, H. 2007. Contemporary museum practice in Cusco, Peru. En Archaeology and Capitalism: From Ethics to Politics, editado por H. Silverman, pp. 195-211. Left Coast Press, Walnut Creek.

Tang, P. 2016. Discover Peru. 3era edición. Lonely Planet, New York. 